\title{
Investigations into the Mechanism of Solvolysis of 3-aryloxybenzisothiazoles ${ }^{\dagger}$
}

\author{
Amin Ismael, ${ }^{\text {a,b }}$ David J.P. Gago, ${ }^{a}$ Lília I.L. Cabral, ${ }^{a}$ Rui Fausto, ${ }^{b}$ and Maria Lurdes S. Cristiano ${ }^{\mathrm{a}, *}$ \\ ${ }^{\mathrm{a} C C M A R}$ and Department of Chemistry and Pharmacy, FCT, University of Algarve, \\ Campus de Gambelas, Faro 8005-039, Portugal \\ ${ }^{\mathrm{b}}$ CQC, Department of Chemistry, University of Coimbra, P-3004-535 Coimbra, Portugal
}

RECEIVED MAY 9, 2014; REVISED JUNE 10, 2014; ACCEPTED JUNE 14, 2014

\begin{abstract}
The solvolysis of selected 3-aryloxybenzisothiazoles (6a-c; Figure 1) in alcohols has been theoretically investigated. The geometries of ethers $6 \mathrm{a}-\mathrm{c}$ were fully optimized at the DFT(O3LYP) level, with the $6-31++\mathrm{G}(\mathrm{d}, \mathrm{p})$ and $6-311++\mathrm{G}(3 \mathrm{df}, 3 \mathrm{pd})$ basis sets. Calculations including solvation effects were performed with the $6-31++\mathrm{G}(\mathrm{d}, \mathrm{p})$ basis set. Overall, theoretical values for bond lengths and angles around the central ether linkage in ethers $6 \mathrm{a}-\mathrm{c}$ are very close, for the isolated molecule and in methanol, and are also very close to those obtained by X-ray crystallography, revealing that the nature of the substituent on the aryl system has a negligible effect on geometric parameters around the ether linkage. The same applies to charge distributions, predicted using the NPA approach. However, measured rate constants for the solvolysis of the same compounds in alcohols show that the rate is affected by the electron-withdrawing/donating characteristics of the substituent on the aryl ring and by the polarity of solvent. Two general pathways were considered for the solvolysis of ethers 6: associative (addition-elimination) or dissociative (fragmentation-recombination) mechanisms. Molecular orbital calculations by means of polarized continuum model $(\mathrm{PCM})$ reaction field predicted that solvolysis of ethers 6 prefers an addition-elimination mechanism.

Calculations show also that a dissociative mechanism for the solvolysis of ethers $6 \mathrm{a}-\mathrm{c}$ is energetically much more demanding than its addition-elimination counterpart and is therefore a highly improbable pathway for the solvolysis. In addition, it was found that the putative cation intermediate formed during a dissociative process should easily convert into its 2-cyanobenzenesulfone cation isomer, via cleavage of the $\mathrm{S}-\mathrm{N}$ bond.
\end{abstract}

Keywords: saccharins, saccharyl ethers, solvolysis, mechanistic investigations, structural and solvent effects

\section{INTRODUCTION}

Benzisothiazoles, also known as saccharins, are heterocyclic compounds with many relevant applications. The parent compound, saccharin (1,2-benzisothiazol-3(2H)one1,1-dioxide), ${ }^{1}$ is a commonly known substance and the oldest artificial sweetener. ${ }^{2}$ Moreover, saccharin and its anion, saccharinate, act as ligands in coordination chemistry $^{3,4}$ and have recently been considered for the formulation of amide-based ionic liquids. ${ }^{5-8}$ Some saccharyl derivatives show biological activity, such as herbicidal, ${ }^{9,10}$ antimicrobial and antifungal, ${ }^{11-14}$ potential in enzymatic inhibition ${ }^{15}$ or anti-HIV-1 activity. ${ }^{16}$

Benzisothiazoles are also relevant in organic and bioorganic synthesis. Saccharin is a cheap and versatile starting material for the preparation of related heterocyclic derivatives and a key building block of industrially developed biologically active compounds. ${ }^{17-19}$ Addi-

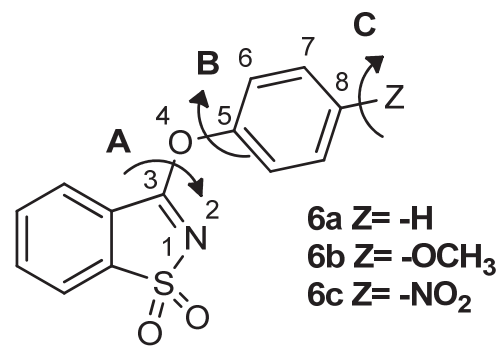

Figure 1. Structure of aryloxysaccharins 6 investigated. The atom numbering adopted is shown. Arrows A, B, C relate to conformationally relevant degrees of freedom. A represents the dihedral angle defined as $\mathrm{N}_{2} \mathrm{C}_{3}-\mathrm{O}_{4} \mathrm{C}_{5}$ and $\mathbf{B}$ represents the dihedral angle defined as $\mathrm{C}_{3} \mathrm{O}_{4}-\mathrm{C}_{5} \mathrm{C}_{6}$. Dihedral $\mathbf{C}$ is not considered for phenoxysaccharin 6a $(\mathrm{X}=\mathrm{H})$; for 4-methoxyphenoxysaccharin $\mathbf{6 b}, \mathbf{C}$ represents the dihedral angle defined as $\mathrm{C}_{7} \mathrm{C}_{8}-\mathrm{O}_{9} \mathrm{C}_{10}$ and for 4-nitrophoenoxysaccharin $\mathbf{6 c}, \mathbf{C}$ represents the dihedral angle defined as $\mathrm{C}_{7} \mathrm{C}_{8}-\mathrm{N}_{9} \mathrm{O}_{10}$.

$\dagger$ Dedicated to Dr. Mirjana Eckert-Maksić on the occasion of her $70^{\text {th }}$ birthday.

* Author to whom correspondence should be addressed. (E-mail: mcristi@ualg.pt) 


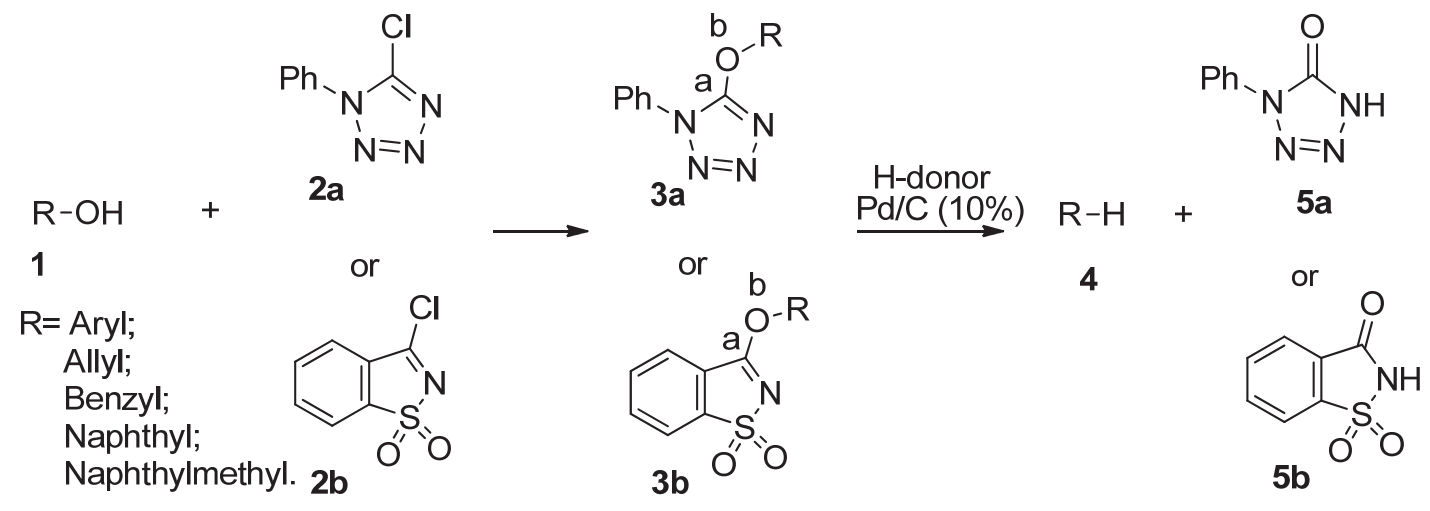

Scheme 1.

tionally, benzisothiazoles are structurally very challenging and belong to a group of heterocycles that play a major role in the design of synthetic methods. Due the strong electron-withdrawing properties of the heterocycles, the halides 5-chloro-1-phenyl tetrazole ${ }^{20}$ and 3chloro-1,2-benzisothiazole 1,1-dioxide (2a,b; Scheme 1) have been explored as derivatising agents for alcohols, prior to reductive cleavage of the $\mathrm{C}-\mathrm{O}$ bond catalysed by transition metals. ${ }^{21-25}$ Reduction of the $\mathrm{C}-\mathrm{OH}$ bond in the alcohol is achieved after etherification of the hydroxyl group (3a,b; Scheme 1). Derivatization weakens the $\mathrm{C}-\mathrm{O}$ bond of the original alcohol, so that addition during catalytic transfer hydrogenolysis occurs selectively across this longer bond. This methodology makes use of hydrogen donors, thus avoiding the use of molecular hydrogen, and presents a practical and selective synthetic alternative to other methods. ${ }^{26-28}$ The side products, tetrazolone ${ }^{29} \mathbf{5 a}$ or saccharin ${ }^{1} \mathbf{5 b}$, are watersoluble and the catalyst is easily filtered off and may be re-used.

Ground state structural features are often used for predicting and interpreting the outcome of reactions. ${ }^{30,31}$ The effect of the heterocyclic part on the $\mathrm{C}-\mathrm{O}$ bond strength in aryl, ${ }^{32}$ naphthyl, ${ }^{32}$ allyl, ${ }^{33,34}$ benzyl ${ }^{24,35}$ and naphthylmethyl ethers ${ }^{25}$ has been assessed through structural analysis obtained by X-ray crystallography. Reported crystal structures for aryloxy- and naphthoxy- tetrazoles and benzisothiazoles ${ }^{32}$ reveal that the central ether linkage (3; Scheme 1) is much shorter on the saccharyl or tetrazolyl ether side $(\mathrm{C}-\mathrm{O} b$ around $132 \mathrm{pm})$ than on the aryl or naphthyl side ( $\mathrm{O}-\mathrm{C} a$ around $143 \mathrm{pm})$, with $\mathrm{C}-\mathrm{O}-\mathrm{C}$ bond angles around $117^{\circ}$. As may be deduced from crystallographic analysis, in these heteroaromatic ethers the ether oxygen appears to show an $\mathrm{sp}^{2}$ hybridization $^{32}$ and is strongly conjugated with the saccharyl or tetrazolyl ring system but not with that of phenyl or naphthyl substituents. The X-ray analyses also show that the plane of the naphthyl or aryl ring is at right angles to that of the saccharyl system. If $O$ conjugates with the carbon atom of the heteroaromatic system through an $\mathrm{sp}^{2}$ hybrid, then it cannot also conjugate with the aromatic carbon. Indeed, in these molecules the $\mathrm{O}-\mathrm{C} a$ bond is much closer in strength to an aliphatic $\mathrm{C}-\mathrm{O}$ bond than in the original phenols or naphthols. This change in structure upon derivatization, instrumental for success in transfer ipso-replacement reactions, ${ }^{32}$ can be ascribed to the saccharyl and the tetrazolyl systems which, together with oxygen, act as excellent leaving groups.

In view of the structural features described, it appeared important to assess the stability of saccharyl ethers in solution, especially when the solvent can act as a nucleophile. For nucleophilic attack on the same aryl ethers, the carbon atom of the $\mathrm{C}-\mathrm{O}-\mathrm{C}$ moiety that lies in the heteroaromatic system $\left(\mathrm{C}_{3}\right.$, Scheme 2$)$ is expected<smiles>[R]OC1=NS(=O)(=O)c2ccccc21</smiles>

$\mathrm{Z}=4 \mathrm{NO}_{2} ; 4 \mathrm{CF}_{3} ; 4 \mathrm{Br} ; 4 \mathrm{Cl} ; 4 \mathrm{~F} ; 4 \mathrm{CH}_{3} ; 4 \mathrm{OMe}$; $\mathrm{H} ; 3 \mathrm{NO}_{2} ; 3 \mathrm{CF}_{3} ; 3 \mathrm{Br} ; 3 \mathrm{Cl} ; 3 \mathrm{~F} ; 3 \mathrm{CH}_{3} ; 3 \mathrm{OMe}$.

Scheme 2. 
to be more susceptible than the other $\mathrm{C}$-atom in the ether linkage $\left(\mathrm{C}_{5}\right.$, Scheme 2$)$, because it is more positively charged. In previous work ${ }^{35} 3$-(4-nitrophenoxy) 1,2-benzisothiazole1,1-dioxide and 3-(4-methoxyphenoxy) 1,2-benzisothiazole 1,1-dioxide $\left(6, \mathrm{Z}=4-\mathrm{NO}_{2}\right.$ and $4-\mathrm{CH}_{3} \mathrm{O}$, respectively) were refluxed with ethanol. The aryl saccharyl ether bearing the electronwithdrawing nitro group was readily converted into ethyl saccharyl ether 7, but the ether with the electrondonating methoxy group was found to be unreactive towards solvolysis, even when refluxed for extended periods of time. It may be argued that, for the 4nitrophenoxy derivative, the ether bond is labile because it suffers the influence of the electron withdrawing 4-nitrophenyl and of the electron deficient heteroaromatic saccharyl ring. Similar behaviour was observed for 2,6-dinitrophenyltriflate ${ }^{36}$ and 2,6dinitrophenyltosylate. ${ }^{37}$ Likewise, for 3-(4-methoxyphenoxy) 1,2-benzisothiazole 1,1-dioxide, the electron-donating 4-methoxyphenyl would offset partly the electron-withdrawing effect of the saccharyl ring. It could be hypothesized that the charge density at $\mathrm{C}_{3}$ would be higher in this ether than in 3-(4-nitrophenoxy) 1,2-benzisothiazole 1,1-dioxide, making the nucleophilic substitution much more difficult for the former than for the latter.

The preliminary results described by Johnstone ${ }^{35}$ prompted us to further investigate the mechanism of solvolysis of aryloxybenzisothiazoles 6. Kinetic studies were conducted for a library of ethers $\mathbf{6}$ in different alcohols (Scheme 2). ${ }^{36}$ Results of these studies have consistently shown that the rate of solvolysis is highly dependent on the substitution pattern and nature of the substituent on the aryl ring. Electron-withdrawing groups $\mathrm{Z}$ were found to increase the rate while electrondonating groups were found to decrease it. The rate of solvolysis was also found to increase substantially with increasing dielectric constant of the solvent. ${ }^{36}$

Considering that bond lengths are related to reactivity and electronegativity, ${ }^{30,31}$ differences in the relative ether bond lengths for ethers $6\left(\mathrm{R}=4-\mathrm{NO}_{2}\right.$ and $\mathrm{R}=$ $4-\mathrm{CH}_{3} \mathrm{O}$ ) could also be hypothesized. However, analysis of reported bond lengths and angles for these ethers, obtained by X-ray crystallography, shows that the ether bond lengths $\mathrm{C}_{3}-\mathrm{O}_{4}$ and $\mathrm{O}_{4}-\mathrm{C}_{5}$ are 133.5 and 141.7 , and 133.1 and 142.4 pm respectively, revealing no significant difference with the electronic nature of the substituent on the aryl ring, in the crystal. ${ }^{35}$ Thus, the opposite electronic effects of nitro and methoxy substituents have no opposed effect on the $\mathrm{C}_{3}-\mathrm{O}_{4}-\mathrm{C}_{5}$ bond lengths, and the explanation for different chemical behaviour in solvolysis of these ethers cannot be found in groundstate electronic features in the crystal. However, electronic features for the same compounds in solution or in the gas-phase can vary substantially from those ob- served in solid state and the changes may translate in different reactivity.

We now describe results of a theoretical study on the solvolysis of ethers $\mathbf{6}$ in alcohols, aimed at complementing our data from kinetic studies and Linear Free Energy Relationship analysis. An addition/elimination mechanism is proposed.

\section{EXPERIMENTAL}

All the calculations were performed with the Gaussian 09 program package. Functionals and basis sets were applied as defined in Gaussian. ${ }^{38}$ The quantum chemical calculations were performed at the DFT level of theory using either the valence double- $\zeta$ polarized 6$31++\mathrm{G}(\mathrm{d}, \mathrm{p})$ or the extended valence triple- $\zeta$ polarized 6 $311++\mathrm{G}(3 \mathrm{df}, 3 \mathrm{pd})$ basis set ${ }^{39-43}$ and the O3LYP ${ }^{44}$ functional. Inclusion of both diffuse and polarization functions in the basis set has been shown to be required for the accurate description of the structure of this type of molecules, as reflected, for example, in the modelling of their infrared spectra. ${ }^{1,45-47}$ This requirement results essentially from the presence in the molecules of hypervalent $\mathrm{S}$ atoms, as indicated by the strong improvement of the calculated vibrational data for the $>\mathrm{SO}_{2}$ stretching and bending modes (compared to other vibrations) upon inclusion in the basis set of diffusion and polarization functions. ${ }^{47,48}$ The use of the DFT/B3LYP or O3LYP method with the $6-311++\mathrm{G}(3 \mathrm{df}, 3 \mathrm{dp})$ basis set was found to be appropriate to attain reliable results at moderate computational effort. ${ }^{1,45-49}$

In the present study, geometries were optimized using the Direct Inversion in the Iterative Subspace (DIIS) method. ${ }^{50}$ Vibrational frequencies were calculated at the same level of theory and the nature of the stationary points on the potential energy surface (PES) resulting from optimization was determined by inspection of the corresponding calculated Hessian matrix. Absence of imaginary frequencies indicated that they correspond to true minima. This also enabled the determination of thermodynamic quantities such as zeropoint-corrected vibrational energy and free energy at $298.15 \mathrm{~K}$. The charge distribution has been analyzed using the Natural Population Analysis (NPA) performed at the optimized geometries obtained at the DFT/O3LYP level. ${ }^{51}$ Solvation effects were included through the use of the polarizable continuum model (PCM), using the integral formalism variant (IEFPCM), as implemented in Gaussian 09, and the internal parameters defined for the used solvents. ${ }^{52,53}$ Geometry optimization calculations with solvation effects included were done at the O3LYP/6-31++G(d,p) level, using the optimized gas-phase geometries obtained at this level as starting geometries. 


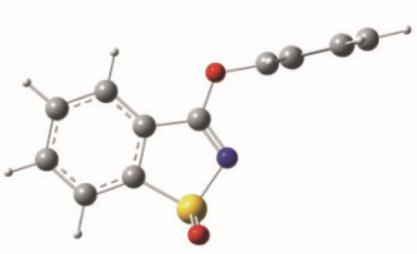

$6 a$

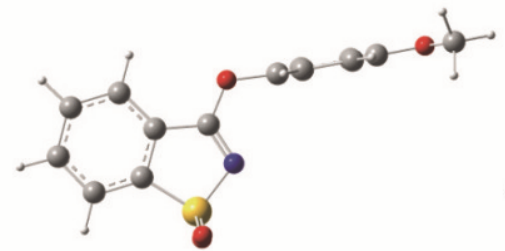

$6 b$

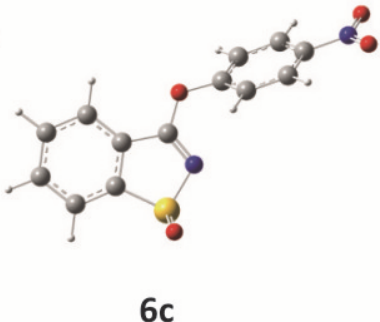

$6 c$

Figure 2. DFT(O3LYP)/6-311++G(3df,3pd) optimized structures of the global minima of monomeric aryloxysaccharins 6a-c. Optimized geometries are provided in Table S3 (Supporting Information).

\section{RESULTS AND DISCUSSION}

The solvolysis of ethers 6 in alcohols was investigated theoretically. Because X-ray data are available for ethers $6\left(\mathrm{Z}=\mathrm{NO}_{2}, \mathrm{OCH}_{3}\right),{ }^{35}$ these were chosen for our study, allowing for results of the calculations to be compared with those obtained for the condensed state.

\section{Molecular Geometry and Charge Density Analysis of the Studied Aryl Saccharyl Ethers}

The ethers investigated $\left(\mathbf{6} ; \mathrm{Z}=\mathrm{H}, \mathrm{NO}_{2}, \mathrm{OCH}_{3}\right)$ have two $(\mathrm{Z}=\mathrm{H})$ and three $\left(\mathrm{Z}=\mathrm{NO}_{2}, \mathrm{OCH}_{3}\right)$ intramolecular rotational degrees of freedom, represented by arrows in Figure 1, that may result in different conformers. These are related with: (i) the relative orientation of the saccharyl and aryl rings (dihedral angles $\mathbf{A}$ and $\mathbf{B}$; for dihedral $\mathbf{A}$, only the zusammen (Z) orientation was considered, since conformations where the aryl ring is directed to the phenyl group of the saccharin moiety are expected to correspond to structures of high energy, due to hindrance); (ii) the relative orientation of the substituent and the aryl ring (dihedral angle $\mathbf{C})$.

The O3LYP/6-311++G(3df,3pd) fully optimized geometries of the global minimum of the studied molecules are presented in Figure 2. In all these structures, the $\mathrm{C}-\mathrm{O}-\mathrm{C}$ ether linkage was found to stay nearly in the plane of the saccharyl moiety. For the unsubstituted phenoxysaccharin $(\mathbf{6 a} ; \mathrm{Z}=\mathrm{H})$, the potential energy profile for internal rotation around the dihedral angle $\mathbf{B}$ calculated at the O3LYP/6-31++G(d,p) level revealed that in the global minimum conformation the $\mathbf{B}$ dihedral is $-92^{\circ}$, i.e., the phenyl substituent is nearly perpendicular to the plane of the heterocycle. In case of the two phenyl-substituted compounds (6b and $\mathbf{6 c}$ ), the calculations also predicted the phenyl and saccharyl planes as being nearly perpendicular to each other, while the phenyl substituents $\left(4-\mathrm{OCH}_{3}\right.$ and $\left.4-\mathrm{NO}_{2}\right)$ stay approximately aligned with the plane of the aromatic ring. For 4-methoxyphenoxysaccharin $\left(6 \mathbf{b} ; \mathrm{Z}=4-\mathrm{OCH}_{3}\right)$, the potential energy surface has its global minimum for the conformation where dihedral $\mathbf{B}$ is $-95^{\circ}$ and dihedral $\mathbf{C}$ is $-179^{\circ}$. For 4-nitrophenoxysaccharin $\left(\mathbf{6 c} ; \mathrm{Z}=4-\mathrm{NO}_{2}\right)$, the global minimum conformation was predicted to correspond to the structure where dihedral $\mathbf{B}$ is $119^{\circ}$ and dihedral $\mathbf{C}$ is $-180^{\circ}$.

Table 1 shows selected bond lengths and angles around the central ether linkage and dihedral angles for aryloxysaccharins 6 investigated, obtained from calculations with the $6-311++\mathrm{G}(3 \mathrm{df}, 3 \mathrm{pd})$ and $6-31++\mathrm{G}(\mathrm{d}, \mathrm{p})$ basis sets. Structure calculations were also performed in methanol, at the O3LYP/6-31++G(d,p)level, using a Polarizable Continuum Model (PCM). The corresponding parameters determined by X-ray crystallography, available for 4-methoxyphenylsaccharin $\mathbf{6 b}$ and 4nitrophenylsaccharin $\mathbf{6 c}$, are also included in the Table 1. For both aryloxysaccharins $\mathbf{6 b}$ and $\mathbf{6 c}$, the calculated lengths for $\mathrm{O}_{4}-\mathrm{C}_{5}(a)$ and $\mathrm{C}_{3}-\mathrm{O}_{4}(b)$ bonds are around $140 \mathrm{pm}$ and $133 \mathrm{pm}$, respectively, similar to those observed in the crystalline state ( $c a .142$ and $133 \mathrm{pm}$ ). Calculated values for the $\mathrm{C}-\mathrm{O}-\mathrm{C}$ angle are close to $120^{\circ}$, also similar to those obtained in the crystals, and are indicative of a significant degree of $\mathrm{sp}^{2}$ character on oxygen. The values obtained theoretically for the geometric parameters of the central ether linkage in the 3 studied molecules are also very similar for the isolated molecule (for both basis sets) and in methanol (see Table 1). Overall, the results reveal that the electronic nature of the substituent on the aryl system has very little or no effect on geometric parameters of the ether linkage, even in methanol. Nevertheless, the calculations show that for the nitro-substituted phenoxysaccharin $6 \mathbf{c}$ the relative orientation of the aryl ring to the saccharyl system changes somewhat in methanol, with the dihedral angle $\mathbf{B}$ varying from around $120^{\circ}$ (as found theoretically for the isolated molecule and in the crystalline phase) to about $95^{\circ}$, a value more similar to those calculated for the isolated molecule or observed in the crystalline phase in compounds $\mathbf{6 a}$ and $\mathbf{6 b}$. Thus, for the most polar ether, the polar solvent induces a significant change in the relative orientation of the two rings, while keeping the structure of the $\mathrm{C}-\mathrm{O}-\mathrm{C}$ linkage practically unaltered.

The charge distribution for aryloxysaccharins $\mathbf{6 a}-\mathbf{c}$, has been analyzed using the Natural Population Analysis (NPA). Atomic charges for sulfur $\mathrm{S}_{1}$, nitrogen 
Table 1. Relevant geometric parameters for phenoxysaccharin (6a), 4-methoxyphenoxysaccharin (6b) and 4nitrophenoxysaccharin $(\mathbf{6 c})$, calculated at the DFT O3LYP 6-31++G(d,p) and 6-311++G(3df,3pd) levels of theory. For comparative purposes, selected structural data obtained from X-ray crystallography are included ${ }^{\mathrm{a}}$

\begin{tabular}{|c|c|c|c|c|c|c|c|}
\hline \multirow{3}{*}{ Molecule } & \multicolumn{3}{|c|}{ Dihedral angle $/^{\circ}$} & \multicolumn{2}{|c|}{ Bond length / pm } & \multirow[t]{2}{*}{ Angle / ${ }^{\circ}$} & \multirow{3}{*}{ Basis } \\
\hline & $\Delta$ & $\mathrm{P}$ & $C$ & $\boldsymbol{b}$ & $a$ & & \\
\hline & $\mathrm{A}$ & $D$ & $c$ & $\mathrm{C}_{(3)}-\mathrm{O}_{(4)}$ & $\mathrm{O}_{(4)}-\mathrm{C}_{(5)}$ & $\mathrm{C}_{(3)} \mathrm{O}_{(4)} \mathrm{C}_{(5)}$ & \\
\hline \multirow{3}{*}{$6 a$} & 0.00 & -92.28 & - & 133.7 & 140.9 & 119.4 & $631++\mathrm{G}(\mathrm{d}, \mathrm{p})$ \\
\hline & 0.00 & -92.20 & - & 133.0 & 140.5 & 119.5 & $6311++\mathrm{G}(3 \mathrm{df}, 3 \mathrm{pd})$ \\
\hline & 0.00 & -92.39 & - & 132.7 & 141.2 & 119.8 & methanol \\
\hline \multirow{4}{*}{$6 \mathbf{b}$} & -0.27 & -95.10 & -179.33 & 133.6 & 141.0 & 119.3 & $631++\mathrm{G}(\mathrm{d}, \mathrm{p})$ \\
\hline & -0.26 & -94.96 & -179.27 & 132.9 & 140.6 & 119.4 & $6311++\mathrm{G}(3 \mathrm{df}, 3 \mathrm{pd})$ \\
\hline & -3.2 & -93.7 & -177.4 & 133.1 & 142.4 & 116.8 & X-ray \\
\hline & -0.58 & -93.24 & -179.81 & 132.7 & 141.3 & 119.8 & Methanol \\
\hline \multirow{4}{*}{$6 c$} & -3.72 & 118.60 & -179.99 & 134.3 & 139.7 & 120.4 & $631++\mathrm{G}(\mathrm{d}, \mathrm{p})$ \\
\hline & -4.21 & 120.80 & -179.97 & 133.6 & 139.3 & 120.8 & $6311++\mathrm{G}(3 \mathrm{df}, 3 \mathrm{pd})$ \\
\hline & -9.4 & 119.8 & -177.1 & 133.5 & 141.7 & 118.7 & X-ray \\
\hline & -0.02 & 94.78 & -179.83 & 133.3 & 140.0 & 119.9 & methanol \\
\hline
\end{tabular}

(a) For definition of the geometric parameters see Figure 1.

$\mathrm{N}_{2}$, carbons $\mathrm{C}_{3}, \mathrm{C}_{5}$ and oxygen $\mathrm{O}_{4}$, and the dipole moments for the molecules, are included in Table 2 (see Figure 1 for atom numbering). The most electronegative natural charges are accumulated on the nitrogen $\mathrm{N}_{2}$ from the saccharin moiety $(-0.7 e)$ and on the oxygen $\mathrm{O}_{4}$ from the ether bridge $(-0.4 e)$. As expected, the most electropositive atom is carbon $\mathrm{C}_{3}$, suffering from the electronwithdrawing effect of both the saccharyl ring and the ether oxygen. Comparing relative charges in those atoms for compounds $\mathbf{6 a}, \mathbf{6 b}$ and $\mathbf{6 c}$, we can see that the electronic nature of the substituent has little or no effect on charge at carbon $\mathrm{C}_{3}$. However, as expected, substituent effects are significant on carbon $\mathrm{C}_{5}$ of the aryl ring. The electron donating 4-methoxyphenyl group on $\mathbf{6 b}$ raises the charge density in carbon $\mathrm{C}_{5}$, compared to the unsubstituted ether $\mathbf{6 a}$, while the electron withdrawing 4-nitrophenyl group in $\mathbf{6 c}$ lowers the charge density of the same carbon $\mathrm{C}_{5}$.

In order to gather more information regarding the effect of solvent in the solvolysis mechanisms for each compound, quantum chemical calculations were performed for the compound in methanol, using the PCM method, at the DFT(O3LYP)/6-31++G(d,p) level of theory. The atomic charges calculated in methanol follow the trends observed for the isolated molecules, but a higher dipole moment is predicted, induced by the polar solvent (Table 2). The relative energies obtained in methanol are presented in Table 3. The values of $\Delta \mathrm{H}^{\circ}$, relative to the heat of dissolution, are relatively constant for all three compounds. The average value is $50.58 \mathrm{~kJ}$

Table 2. NPA partial charges on selected atoms of phenoxysaccharin (6a), 4-methoxyphenoxysaccharin (6b) and 4nitrophenoxysaccharin $(\mathbf{6 c})$, and resulting dipole moment $(|\mu|)$, as calculated at the DFT(O3LYP)/6-31++G(d,p) level of theory, in vacuum, and in methanol (using the PCM approach) ${ }^{\mathrm{a}}$

\begin{tabular}{cccccccc}
\hline \multirow{2}{*}{ Molecule } & \multicolumn{9}{c}{ NPA Charges $(q)$} & \multicolumn{1}{c}{$|\mu|$} & \\
\cline { 2 - 5 } & $\mathrm{S}_{1}$ & $\mathrm{~N}_{2}$ & $\mathrm{C}_{3}$ & $\mathrm{O}_{4}$ & $\mathrm{C}_{5}$ & & \\
\hline $\mathbf{6 a}$ & 2.410 & -0.713 & 0.589 & -0.487 & 0.273 & 6.13 & vacuum \\
$\mathbf{6 b}$ & 2.239 & -0.709 & 0.589 & -0.485 & 0.244 & 6.09 & \\
$\mathbf{6 c}$ & 2.238 & -0.765 & 0.584 & -0.486 & 0.307 & 8.79 & methanol \\
\hline $\mathbf{6 a}$ & 2.247 & -0.757 & 0.617 & -0.472 & 0.263 & 8.85 & \\
$\mathbf{6 b}$ & 2.247 & -0.759 & 0.628 & -0.470 & 0.233 & 8.84 & 12.13 \\
$\mathbf{6 c}$ & 2.247 & -0.749 & 0.614 & -0.472 & 0.307 & \\
\hline
\end{tabular}

a See Figure 1 for schematic drawings and atom numbering. Atomic charges $(q)$ are in units of electron; Dipole moment $|\mu|$ in Debye. 
Table 3. Relative energies for aryloxysaccharins $\mathbf{6 a}-\mathbf{c}$ in methanol, calculated with a Polarizable Continuum Model (PCM) using the integral formalism variant (IEFPCM), at the DFT (O3LYP)/6-31++G(d,p) level of theory

\begin{tabular}{lcccc}
\hline \multirow{2}{*}{ Molecule } & \multicolumn{4}{c}{ Relative energy / $\mathrm{kJ} \mathrm{mol}^{-1}$} \\
\cline { 2 - 4 } & $\Delta E_{\mathrm{el}}$ & $\Delta E_{\mathrm{ZPVE}}$ & $\Delta H^{\mathrm{o}}$ & $\Delta G^{\mathbf{0}}$ \\
\hline $\mathbf{6 a}$ & -45.06 & -45.21 & -45.38 & -42.79 \\
$\mathbf{6 b}$ & -49.61 & -49.98 & -50.09 & -48.35 \\
$\mathbf{6 c}$ & -55.86 & -56.63 & -56.58 & -56.72 \\
\hline
\end{tabular}

All relative energies are calculated with respect to the corresponding structure calculated as in vacuo. $\Delta E_{\mathrm{el}}, \Delta E_{\mathrm{ZPVE}}, \Delta H^{\mathrm{o}}, \Delta G^{\mathrm{o}}$ state for the relative electronic, zero-point-corrected, enthalpy (at $298.15 \mathrm{~K}$ ) and Gibbs free energy (at $298.15 \mathrm{~K}$ ), respectively. The absolute values calculated as in vacuo at the DFT $(\mathrm{O} 3 \mathrm{LYP}) / 6-31++\mathrm{G}(\mathrm{d}, \mathrm{p})$ level are: 6a $\left(E_{\mathrm{el}}=-1179.09846759\right.$, $E_{\mathrm{ZPVE}}=-1178.902984, E_{\mathrm{H} 298}=-1178.888803, E_{\mathrm{G} 298}=-1178.946860$ hartree $) ; 6 \mathbf{b}\left(E_{\mathrm{el}}=-1293.60410999 ; E_{\mathrm{ZPVE}}=-1293.376320\right.$, $E_{\mathrm{H} 298}=-1293.358627, E_{\mathrm{G} 298}=-1293.404248$ hartree $)$ and $\mathbf{6 c}\left(E_{\mathrm{el}}=-1383.54979714 ; E_{\mathrm{ZPVE}}=-1383.351869, E_{\mathrm{H} 298}=\right.$ $-1383.334171, E_{\mathrm{G} 298}=-1383.399654$ hartree).

$\mathrm{mol}^{-1}$, with a standard deviation of $5.60 \mathrm{~kJ} \mathrm{~mol}^{-1}$. In general, the trends observed in the thermodynamic data for the compounds in methanol are very similar to those calculated for the gas-phase even though, in reactions involving protic solvents, hydrogen bonds are expected to play an important role in thermodynamic parameters and mechanisms involved, but akin in all three molecules investigated.

\section{Effect of solvents with different dielectic constant}

The geometry of phenoxysaccharin 6a was optimized in 5 different alcohols. Table 4 presents the effects of solvent polarity on the energy of $\mathbf{6 a}$ in the ground state. As it can be seen in Table 4, the energy of compound $\mathbf{6 a}$ in alcohols decreases consistently as the dielectric constant of the solvent increases. This stabilizing effect of the solvent polarity is in fact expected to be even stronger for compound $\mathbf{6 c}$, due the higher relative polarity of this compound. Results from kinetic studies have shown that the rate of solvolysis for these ethers increases consistently with increasing the dielectric constant of the solvent. $^{36}$

\section{Mechanism of Solvolysis}

Two general mechanistic pathways for the solvolysis of aryloxybenzisothiazoles 6 were considered, paths a (i), and $\mathrm{b}$ (ii), involving associative or dissociative mechanisms. The two possibilities are schematically represented in Figure 3, using a diagram adapted from the More O'Ferrall-Jencks representation. ${ }^{54,55}$

(i) Path $a$ represents an addition-elimination mechanism. Nucleophilic attack by the alcohol leads to a zwitterionic tetrahedral intermediate that may develop to a neutral intermediate through proton exchange mediated by solvent, followed by elimination of the aryloxy ion. In a tetrahedral intermediate, phenoxides are known to be better leaving groups than alkoxides. Also, the initially formed tetrahedral zwitterionic intermediate would be more stabilized in a solvent of higher dielectric constant, in keeping with results obtained for relative rates observed in different alcohols. $^{36}$

(ii) Path $b$ represents a dissociation-recombination mechanism. If the reaction occurred through a dissociative mechanism cleavage of the $\mathrm{C}_{3}-\mathrm{O}_{4}$ bond would be expected in the rate-determining step, leading to iminium and aryloxy ions. As discussed, structural data from solid-state analysis and from quantum chemical calculations for the aryloxybenzisothiazoles $\mathbf{6 a}-\mathbf{c}$ indicate that bond $\mathrm{C}_{3}-\mathrm{O}_{4}$ is very strong. Structural data ob-

Table 4. Relative energies of phenoxysaccharin 6a in alcohols, calculated with a Polarizable Continuum Model (PCM) using the integral formalism variant (IEFPCM), at the DFT (O3LYP)/6-31++G(d,p) level of theory

\begin{tabular}{lccccc}
\hline \multirow{2}{*}{ Solvent } & \multirow{2}{*}{$\varepsilon$} & \multicolumn{5}{c}{ Relative energy/ kJmol ${ }^{-1}$} \\
\cline { 3 - 6 } & & $\Delta E_{\text {el }}$ & $\Delta E_{\text {ZPVE }}$ & $\Delta H^{\mathrm{o}}$ & $\Delta G^{\mathrm{o}}$ \\
\hline Methanol & 32.613 & 0.00 & 0.00 & 0.00 & 0.00 \\
Ethanol & 24.852 & 0.78 & 0.79 & 0.79 & 0.80 \\
1-Propanol & 20.524 & 1.46 & 1.49 & 1.48 & 1.50 \\
2-Propanol & 19.264 & 1.64 & 1.79 & 1.74 & 2.09 \\
1-Buthanol & 17.332 & 2.17 & 2.21 & 2.20 & 2.22 \\
\hline
\end{tabular}

All relative energies are calculated with respect to phenoxysaccharin $\mathbf{6 a}$, in methanol. $\Delta E_{\mathrm{el}}, \Delta E_{\mathrm{ZPVE}}, \Delta H^{\mathrm{o}}, \Delta G^{\mathrm{o}}$ state for the relative electronic, zero-point-corrected, enthalpy (at $298.15 \mathrm{~K}$ ) and Gibbs free energy (at $298.15 \mathrm{~K}$ ), respectively. The absolute values calculated for 6a in methanol at the DFT (O3LYP)/6-31++G(d,p) level are $E_{\mathrm{el}}=-1179.11562919, E_{\mathrm{ZPVE}}=-1178.920205$, $E_{\mathrm{H}}=-1178.905142, E_{\mathrm{G} 298}=-1178.963158$ hartree). $\varepsilon$ is the dielectric constant of the solvents used in the PCM calculation. 


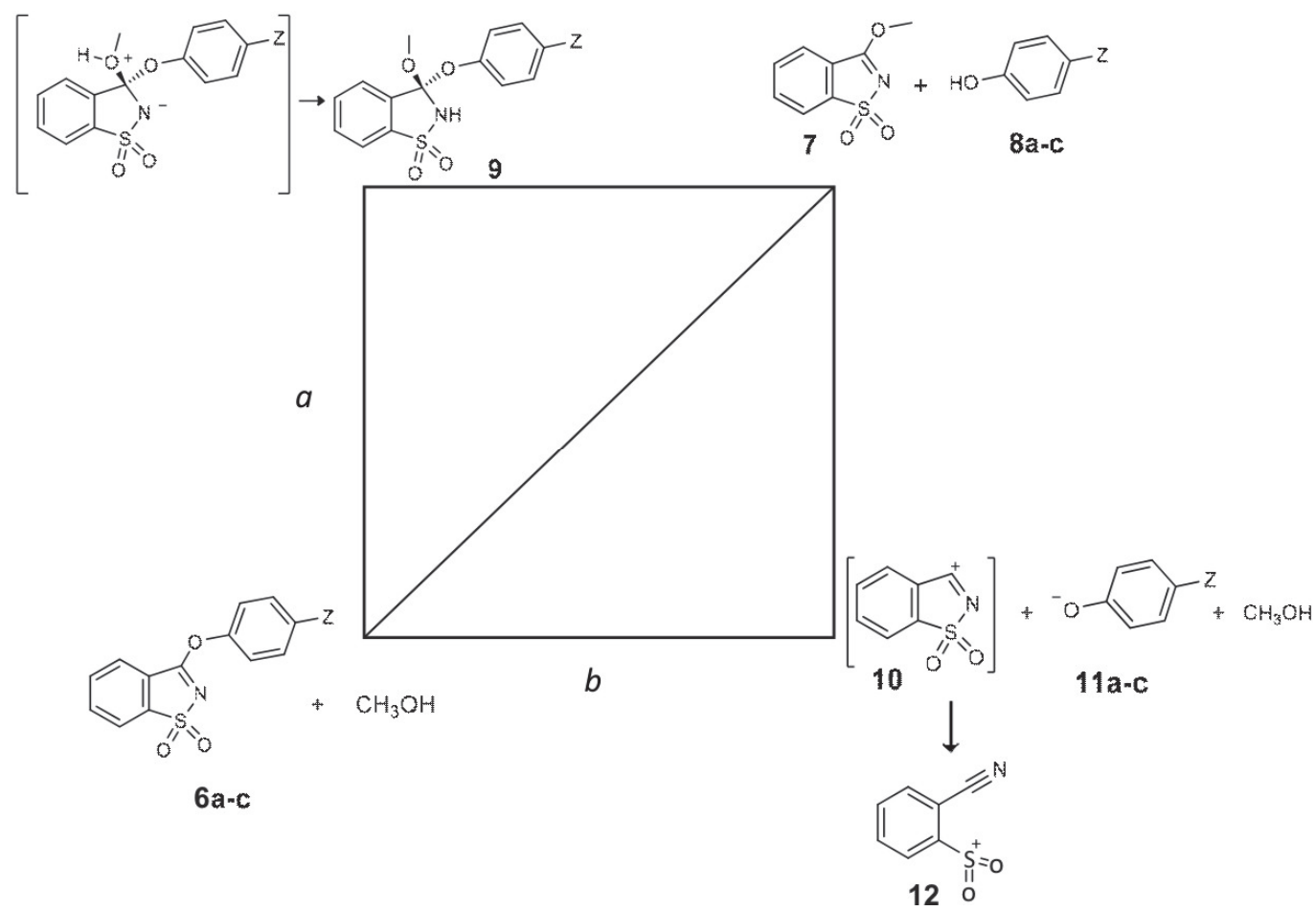

Figure 3. Schematic representation of a More O'Ferrall-Jencks-type diagram for the solvolysis of aryloxybenzisothiazoles 6a-c.

tained through O3LYP/6-31++G(d,p) molecular orbital calculations (Tables 1 and 2) show a $\mathrm{C}_{3}-\mathrm{O}_{4}$ bond length of around $133 \mathrm{pm}$ and an electronic density at the heteroaromatic carbon $\mathrm{C}_{3}$ of about $(0.59 e)$. Cleavage of this bond is expected to require a very high energy of activation and would also be thermochemically disfavored, since it would lead to the formation of a formal positive charge on a carbon that already exhibits a high partially positive charge in the original ether.

To obtain information regarding the energy profiles for both pathways, the energies of the major species involved were calculated. For simplicity and atom economy, we considered methanol as the nucleophile. For pathway $a$, calculations were carried out for ethers $\mathbf{6 a}-\mathbf{c}$. For pathway $b$, only compound $\mathbf{6 a}$ was considered. Results obtained are presented in Figures 4 and 5. As described below, the performed molecular orbital calculations by means of polarized continuum model reaction field predicted that the solvolysis prefers an addition-elimination mechanism.

As proposed in Figure 3 pathway $a$ proceeds through a zwitterionic (ZW) structure that may develop to a neutral intermediate. Both the performed calculations in vacuo and in methanol showed that the ZW intermediate is unstable, with no minimum found for this species in the calculated PES, while the neutral intermediate, which results from nucleophilic addition

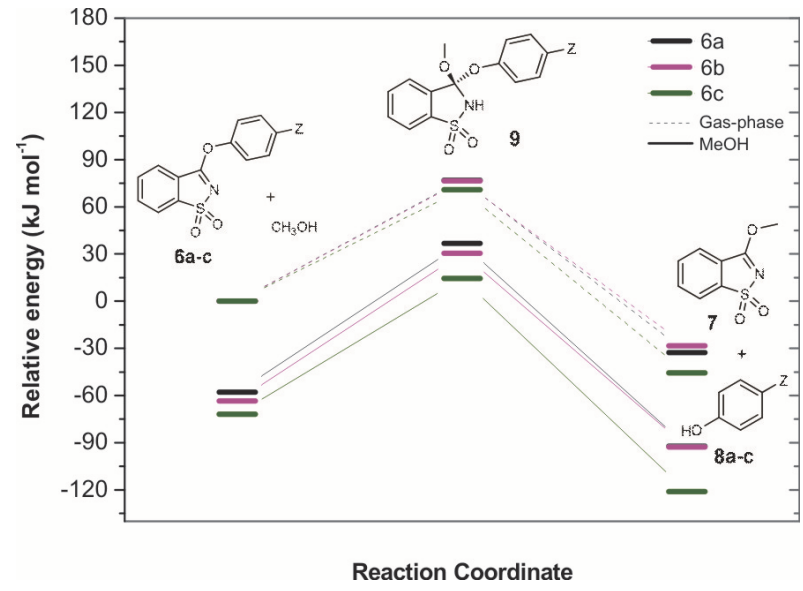

Figure 4. Energy diagram with structures corresponding to the most stable stationary points for solvolysis of aryloxysaccharins $\mathbf{6 a - c}$, with the formation of methoxysaccharin 7 , considering an addition-elimination mechanism, in gas phase and in methanol, calculated at the DFT(O3LYP)/6-31++G(d,p) level of theory. The relative energies $\left(\Delta E_{\mathrm{G} 298}\right)$ are presented in Table 5. In all calculations, the relative zero level of energy was chosen to be the energy of each aryoxysaccharin $\mathbf{6 a}-\mathbf{c}$ plus the nucleophile (methanol) in gas phase. Solvent stabilization effects were evaluated by using the PCM approach with the Integral Formalism variant (IEFPCM).

and proton transfer, was found to be a minimum (in solution, the protic solvent molecules participate in the 


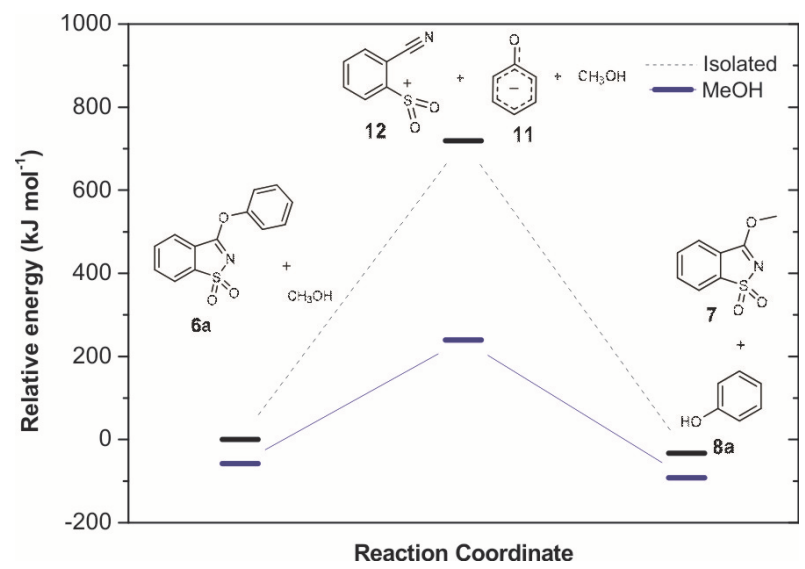

Figure 5. Relative energies of the structures corresponding to the most stable stationary points for the dissociativeassociative mechanism of the aryloxysaccharine $\mathbf{6 a}$, with the formation of methoxysaccharin 7 and phenol $\mathbf{8 a}$, in vacuum and in methanol, calculated at the DFT(O3LYP)/6$31++G(d, p)$ level of theory. Solvent stabilization effects were evaluated by using the PCM approach with the Integral Formalism Variant (IEFPCM).

proton exchange). A realistic solute cavity shape and size with explicit consideration of a large number of specific solvent molecules must be used to accurately evaluate the solvent role in the stabilization of the zwitterionic intermediate. ${ }^{56-60}$ This type of calculations for the present systems is, however, beyond pratical limitations. Thus, in the following discussion, we explored mechanism $a$ considering the neutral intermediate.

In order to examine the effect of substituent on ground state energies of reagents, products and the intermediate formed upon addition of nucleophile, calculations on the gas-phase and in methanol were per- formed on the different systems under study. Table 5 presents the relative energies of species corresponding to the most stable stationary points for the additionelimination mechanism (pathway $a$ ) and the dissociative-associative mechanism (pathway $b$ ) of the aryloxysaccharins $\mathbf{6 a}-\mathbf{c}$, with the formation of methoxysaccharin 7, in gas-phase and in methanol, calculated at the DFT(O3LYP)/6-31++G(d,p) level of theory. For a schematic representation, Figure 4 presents a diagram of the relative energies of species corresponding to the most stable stationary points for the additionelimination mechanism, pathway $a$.

Aryloxysaccharins $\mathbf{6 a}-\mathbf{c}$ and the nucleophile methanol, in gas-phase or methanol, were chosen to be the relative zero level of energy. The relative energies of the structures corresponding to the most stable stationary points for the addition-elimination mechanism (pathway $a$ ) show that the energy for the neutral intermediates from the 3 ethers in the gas phase, is very close, ranging from $71 \mathrm{~kJ} \mathrm{~mol}^{-1}$ in $\mathbf{6 c}$ to $77 \mathrm{~kJ} \mathrm{~mol}^{-1}$ in 6a. Thus, the nature of the substituent has a negligible effect on the relative energy of said intermediates, in the gas phase. However, substituent effects appear to be more pronounced for the products, where calculated energies vary from $-46 \mathrm{~kJ} \mathrm{~mol}^{-1}$, for products resulting from $6 \mathbf{c}$, to $-28 \mathrm{~kJ} \mathrm{~mol}^{-1}$, for products resulting from $\mathbf{6 b}$. Thus, the products from the nitro derivative $\mathbf{6 c}$ are calculated to be more stable (by $18 \mathrm{~kJ} \mathrm{~mol}^{-1}$ ) than those from the methoxy derivative $\mathbf{6 b}$ (Table 5).

As shown in Table 5, relative energies in methanol are consistently smaller than in the gas-phase, by ca. 60 $\mathrm{kJmol}^{-1}$, for reagents and products, and by ca. $45 \mathrm{~kJ}$ $\mathrm{mol}^{-1}$ for the neutral intermediates (see also Figure 4). Additionally, data presented in Table 5 shows that the effect of solvent polarity is more pronounced on the

Table 5. Relative energies $\left(\Delta G^{\mathrm{o}} ; \mathrm{kJ} \mathrm{mol}^{-1}\right)$ of the structures corresponding to the most stable stationary points for the additionelimination mechanism (pathway $a$ ) and the dissociative-associative mechanism (pathway $b$ ) of the aryloxysaccharins 6a-c, with the formation of methoxysaccharin 7, in gas-phase and in methanol as solvent, calculated at the DFT (O3LYP)/6-31++G(d,p) level of theory ${ }^{\mathrm{a}}$

\begin{tabular}{llllll}
\hline & Compound & Reagents & $\begin{array}{l}\text { Intermediates } \\
\text { (pathway } a)\end{array}$ & $\begin{array}{l}\text { Intermediates } \\
\text { (pathway } b \text { ) }\end{array}$ & Products \\
\hline \multirow{3}{*}{ Gas-Phase } & $6 \mathrm{a}$ & 0.00 & 77.07 & 719.10 & -32.62 \\
& $6 \mathrm{~b}$ & 0.00 & 76.36 & - & -28.33 \\
& $6 \mathrm{c}$ & 0.00 & 70.95 & - & -45.62 \\
\hline \multirow{3}{*}{$\mathrm{MeOH}$} & $6 \mathrm{a}$ & $0.00(-57.87)$ & $94.59(36.72)$ & $297.18(239.31)$ & $-34.31(-92.18)$ \\
& $6 \mathrm{~b}$ & $0.00(-63.43)$ & $93.91(30.48)$ & - & $-29.25(-92.68)$ \\
& $6 \mathrm{c}$ & $0.00(-71.80)$ & $86.28(14.48)$ & - & $-49.30(-121.10)$ \\
\hline
\end{tabular}

${ }^{a}$ Schematic representation of reagents, intermediates and products for each pathway mechanism are presented in a More O'FerralJencks-type diagram shown in Figure 3. For the dissociative-associative mechanism only compound 6a was considered. The relative zero level of energy was chosen to be the energy of each aryloxysaccharin 6a-c plus the nucleophile (methanol) in gasphase or methanol respectively. Values in parenthesis correspond to the relative energy in methanol calculated with respect to the corresponding aryloxysaccharin 6a-c plus the nucleophile in the gas-phase. Solvent stabilization effects were evaluated by using the PCM approach with the Integral Formalism variant (IEFPCM). 


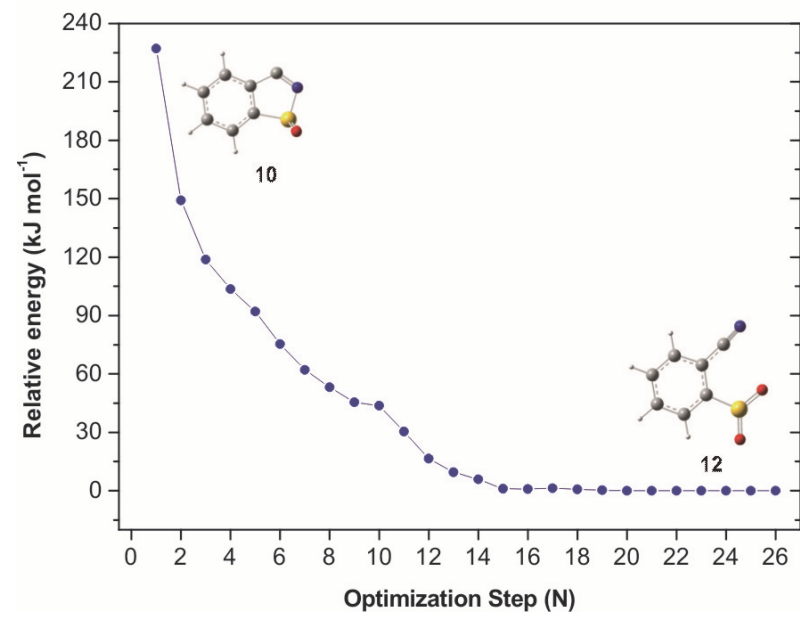

Figure 6. Potential energy profile showing the convergence in energy during optimization of the putative saccharyliminium 10 (formed from cleavage of the $\mathrm{C}-\mathrm{O}$ bond of $\mathbf{6 a}$, leading to aryloxy group and a putative saccharylcation), that rearranges to 2-cyanobenzene sulfone $\mathbf{1 2}$, through a cleavage of the $\mathrm{S}-\mathrm{N}$ bond. Calculations performed at the DFT(O3LYP)/6$311++\mathrm{G}(3 \mathrm{df}, 3 \mathrm{pd})$ level.

reactants than on corresponding intermediates. Regarding substituent effects in methanol, the relative energy of intermediates ranges from $86 \mathrm{~kJ} \mathrm{~mol}^{-1}$, for $\mathbf{6 c}$, to 95 $\mathrm{kJ} \mathrm{mol}^{-1}$, for $\mathbf{6 a}$, showing a stabilizing effect of the nitro substituent corresponding to about $9 \mathrm{~kJ} \mathrm{~mol}^{-1}$. The relative energy of products from ethers $\mathbf{6 a}-\mathrm{c}$ in methanol ranges from $-49 \mathrm{~kJ} \mathrm{~mol}^{-1}$, for $\mathbf{6 c}$, to $-29 \mathrm{~kJ} \mathrm{~mol}^{-1}$, for $\mathbf{6 b}$, showing that the products from the nitro derivative $6 \mathbf{c}$ are calculated to be more stable (by $20 \mathrm{~kJ} \mathrm{~mol}^{-1}$ ) than those from the methoxy derivative $\mathbf{6 b}$. Thus, the substituents induce similar effects on the energy of intermediates and products, in the gas phase and in methanol.

For pathway $b$, only compound $\mathbf{6 a}$ was considered for the theoretical investigation. It is established that the energetic demand of the two processes is determined by the reaction barrier for each process. ${ }^{61,62}$ Many efforts were made to determine reaction barriers. Theoretical calculations of the TS were found to be a true challenge. Unfortunately, the calculated activation barriers in vacuum were too high, and no convergence was achieved. However, considering the large energy difference of the intermediates in pathways $a$, and $b$, it appears reasonable to assume that the energy barriers in processes $a$ and $b$ must indeed be quite different, with the energy barrier associated to process $b$ being much larger (see Figures 4 and 5 and Table 5 for values). The energies calculated for the intermediates associated to pathway $b$, in gasphase and in methanol, are $642.03 \mathrm{~kJ} \mathrm{~mol}^{-1}$ and 202.59 $\mathrm{kJ} \mathrm{mol}^{-1}$, respectively, much higher than those associated to pathway $a$, thus making pathway $b$ a highly im- probable route for the solvolysis. Also, the calculations showed that the putative saccharyl iminium cation $\mathbf{1 0}$ formed from the dissociative process leads to a product resulting from cleavage of the $\mathrm{S}-\mathrm{N}$ bond, the 2cyanobenzene sulfone cation $\mathbf{1 2}$ (see Figure 6), in a barrierless process. A similar ring-opening reaction has been predicted for deprotonated isosaccharin. ${ }^{1}$ Isosaccharin is formed from saccharin, through light-induced isomerisation. ${ }^{1}$

\section{CONCLUSION}

The solvolysis of aryloxybenzisothiazoles 6a-c (Figure 3) has been theoretically investigated in different alcohols. The geometries of the investigated ethers were fully optimized at the DFT(O3LYP) level of theory, with the $6-31++\mathrm{G}(\mathrm{d}, \mathrm{p})$ and $6-311++\mathrm{G}(3 \mathrm{df}, 3 \mathrm{pd})$ basis sets. Calculations including solvation effects were performed with the $6-31++G(d, p)$ basis set. Overall, values obtained theoretically for the central ether linkage in all studied aryloxysacharins are very close, for the isolated molecule, in both basis sets, and in methanol. Furthermore, theoretical values are also very close to those obtained by X-ray crystallography, revealing that the electronic nature of the substituent on the aryl system has very little or no effect on geometric parameters of the ether linkage. The charge distributions predicted using the NPA approach for the studied compounds also show that the electronic nature of the substituent has little or no effect on the charge of the carbon atom of the $\mathrm{C}-\mathrm{O}-\mathrm{C}$ moiety that lies in the heteroaromatic system. However, measured rate constants for the solvolysis of compounds $\mathbf{6 a}-\mathbf{c}$ in methanol, at $40^{\circ} \mathrm{C}$, are $3.84 \times 10^{-4}$ $\mathrm{s}^{-1}$ for ether $6 \mathbf{a}, 0.91 \times 10^{-4} \mathrm{~s}^{-1}$ for ether $6 \mathbf{b}$ and $19.9 \times$ $10^{-4} \mathrm{~s}^{-1}$ for ether $\mathbf{6 c},{ }^{36}$ showing that the rate of solvolysis is affected by the electron-withdrawing/-donating characteristics of the substituent on the aryl ring. Thus, an explanation for observed differences in rate constants for compounds $6 \mathrm{a}-\mathrm{c}$ cannot be rationalized by geometric parameters of the ether linkage or by charge distributions in the ground state of reactants.

Two general mechanistic pathways for the solvolysis of aryloxybenzisothiazoles were considered, involving associative or dissociative mechanisms. Molecular orbital calculations by means of polarized continuum model (PCM) reaction field predicted that solvolysis through the addition-elimination mechanism is preferred. We propose a mechanism whereby initial addition of nucleophile to carbon $\mathrm{C}_{3}$ of the saccharyl system leads to an unstable zwitterionic structure that develops to a neutral intermediate. Comparing the corresponding relative energies for the intermediates and products from the studied compounds, we concluded that the electron donating methoxy substituent induces a minor change in the relative energies, while the electron with- 
drawing nitro substituent has a more significant stabilizing effect on both intermediates and products.

Calculations show also that a dissociativeassociative mechanism for the solvolysis of the studied aryloxysaccharins is energetically much more demanding than its addition-elimination counterpart, making the dissociative-associative pathway a highly improbable route for the solvolysis. In addition, it was found that the putative cation intermediate formed during the dissociative process should easily convert into its 2cyanobenzene sulfone cation isomer, via cleavage of the $\mathrm{S}-\mathrm{N}$ bond.

Supplementary Materials. - Supporting informations to the paper are enclosed to the electronic version of the article. These data can be found on the website of Croatica Chemica Acta (http://public.carnet.hr/ccacaa).

Acknowledgements. The authors gratefully acknowledge Fundação para a Ciência e a Tecnologia, Portugal (Projects PEst-C/MAR/LA0015/2013, PTDC/QUI-QUI/111879/2009), co-funded by QREN-COMPETE-UE, and CCMAR for generous financial support. The Coimbra Chemistry Centre (CQC) is also supported by the FCT through the project PestOE/QUI/UI0313/2014. DJPG and AI acknowledge FCT for the award of doctoral grants (PRAXIS XXI/BD/19973/99 and SFRH/BD/90435/2012).

\section{REFERENCES}

1. L. Duarte, I. Reva, M. de L. S. Cristiano, and R. J. Fausto, Org, Chem. 78 (2013) 3271-3275.

2. V. George, S. Arora, V. Sharma, B. K. Wadhwa, and A. K. Singh, Food Bioprocess Tech. 5 (2010) 323-330.

3. E. J. Baran and V. T. Yilmaz, Coord. Chem. Rev. 250 (2006) 1980-1999.

4. E. J. Baran, Quim. Nova 28 (2005) 326-328.

5. F. Quentel, K. Stankoska, O. Grupče, G. Jovanovski, and V. Mirčeski, Electrochem. Commun. 13 (2011) 1476-1478.

6. Q. Zhang, S. Liu, Z. Li, J. Li, Z. Chen, R. Wang, L. Lu, and Y. Deng, Chemistry 15 (2009) 765-778.

7. E. B. Carter, S. L. Culver, P. A. Fox, R. D. Goode, I. Ntai, M. D. Tickell, R. K. Traylor, N. W. Hoffman, and J. H. Davis, Chem. Commun. (Camb) 2004 630-631.

8. I. A. Shkrob, T. W. Marin, S. D. Chemerisov, J. Hatcher, and J. F. Wishart, J. Phys. Chem. B 116 (2012) 9043-9055.

9. M. Otten, W. Von Deyn, S. Engel, L. R. Hill, U. Kardorff, M. Vossen, P. Plath, H. Walter, K.-O. Westphalen, and U. Misslitz, Isoxazole-4-yl-benzoyl derivatives and their use as herbicides, PCT/EP1996/005069, May 30, 1997.

10. P. J. Wepplo, R. A. Rampulla, G. D. Heffernan, M. V. Cosette, C. M. Langevine, V. Kameswaran, R. E. Diehl, J. J. Fiordeliso, G. J. Haley, and M. A. Guaciaro, Herbicidal 3-heterocyclic substituted benzisothiazole and benzisoxazole compounds, PCT/EP2001/004356, October 26, 2001.

11. M. B. Gravestock, Antibiotic oxazolidinone derivatives, PCT/GB1998/002476, March 05, 1999.

12. D. J. Hlasta, M. R. Bell, J. J. Court, K. C. Cundy, R. C. Desai, E. W. Ferguson, R. J. Gordon, V. Kumar, A. L. Maycock, C. Subramanyam, R. P. Dunlap, S. L. Eiff, C. A. Franke, A. J. Mura, and A. G. Rowlands, Bioorg. Med. Chem. Lett. 5 (1995) 331-336.
13. C. Subramanyam, M. R. Bell, E. Ferguson, R. G. Gordon, R. P. Dunlap, C. Franke, and A. J. Mura, Bioorg. Med. Chem. Lett. 5 (1995) 319-324.

14. L. H. Wang, X. Y. Yang, X. Zhang, K. Mihalic, Y.-X. Fan, W. Xiao, O. M. Z. Howard, E. Appella, A. T. Maynard, and W. L. Farrar, Nat. Med. 10 (2004) 10 40-47.

15. P. I. Eacho, P. S. Foxworthy-Mason, H.-S. Lin, J. E. Lopez, M. K. Mosior, and M. E. Richett, Benzisothiazol-3-one-carboxylic acid amides as phospholipase inhibitors, PCT/US2004/006094, November 05, 2004.

16. L. Sharmeen, T. McQuade, A. Heldsinger, R. Gogliotti, J. Domagala, and S. Gracheck, Antiviral Res. 49 (2001) 101-114.

17. K. H. Ahn, H.-H. Baek, S. J. Lee, and C.-W. Cho, J. Org. Chem. 65 (2000) 7690-7696.

18. J. C. Powers, J. L. Asgian, Ö. D. Ekici, K. E. James, Chem. Rev. 102 (2002) 4639-4750.

19. F. Zani and P. Vicini, Arch. Pharm. (Weinheim) 331 (1998) 219-223.

20. S. C. Bugalho, L. Lapinski, M. L. S. Cristiano, L. M. Frija, and R. Fausto, Vib. Spectrosc. 30 (2002) 213-225.

21. B. J. Hussey, R. A. W. Johnstone, and J. D. Entwistle, Tetrahedron 38 (1982) 3775-3781.

22. R. A. W. Johnstone, A. H. Wilby, and I. D. Entwistle, Chem. Rev. 85 (1985) 129-170.

23. M. Lurdes, S. Cristiano, R. A. W. Johnstone, P. J. Price, and M. L. S. Cristiano, J. Chem. Soc. Trans. 11996 1453-1459.

24. N. C. P. Araujo, A. F. Brigas, M. L. S. Cristiano, L. M. T. Frija, E. M. O. Guimaraes, and R. M. S. Loureiro, J. Mol. Catal. AChem. 215 (2004) 113-120.

25. L. M. T. T. Frija, M. L. S. Cristiano, E. M. O. Guimarães, N. C. Martins, R. M. S. S. Loureiro, J. F. Bickley, and E. M. O. Guimaraes, J. Mol. Catal. A-Chem. 242 (2005) 241-250.

26. R. L. Augustine, Heterogeneous Catalysis for the Synthetic Chemist, CRC Press; $1^{\text {st }}$ ed., 1995, p. 672.

27. P. N. Rylander, Catalytic Hydrogenation in Organic Syntheses, Academic Pr., Illustrated edition, 1979, p. 336.

28. V. S. Ranade and R. Prins, Chemistry 6 (2000) 313-320.

29. L. M. T. Frija, I. D. Reva, A. Gomez-Zavaglia, M. L. S. Cristiano, and R. Fausto, Photochem. Photobiol. Sci. 6 (2007) 1170-1176.

30. P. G. Jones and A. J. Kirby, J. Am. Chem. Soc. 106 (1984) 6207-6212.

31. L. Pauling, The Nature of the Chemical Bond and the Structure of Molecules and Crystals: An Introduction to Modern Structural Chemistry, Cornell University Press, $3^{\text {rd }}$ ed.: Ithaca, 1960, p. 664.

32. J. A. C. Alves, J. V. Barkley, A. F. Brigas, and R. A. W. Johnstone, J. Chem. Soc. Perkin Trans. 21997 669-678.

33. N. C. P. Araujo, P. M. M. Barroca, J. F. Bickley, A. F. Brigas, M. L: S. Cristiano, R. A. W. Johnstone, R. M. S. Loureiro, and P. C. A. Pena, J. Chem. Soc. Trans. 12002 1213-1219.

34. J. V. Barkley, M. L. S. Cristiano, R. A. W. Johnstone, and R. M. S. Loureiro, Acta Crystallogr. Sect. C-Crystal Struct. Commun. 53 (1997) 383-386.

35. A. F. Brigas, P. M. Goncalves, R. A. W. Johnstone, Acta Crystallogr. Sect. C Cryst. Struct. Commun. 54 (1998) 251-253.

36. Gago, D. J. P. al, Unpubl. (in Prep. Tetrahedron).

37. J. Zhu, A. Bigot, and M. Elise, Tetrahedron Lett. 38 (1997) 1181-1182.

38. M. J. Frisch, G. W. Trucks, H. B. Schlegel, G. E. Scuseria, M. A. Robb, J. R. Cheeseman, G. Scalmani, V. Barone, B. Mennucci, G. A. Petersson, H. Nakatsuji, M. Caricato, X. Li, H. P. Hratchian, A. F. Izmaylov, J. Bloino, G. Zheng, J. L. Sonnenberg, M. Hada, M. Ehara, K. Toyota, R. Fukuda, J. Hasegawa, M. Ishida, T. Nakajima, Y. Honda, O. Kitao, H. Nakai, T. Vreven, J. A. Montgomery Jr., J. E. Peralta, F. Ogliaro, M. Bearpark, J. J. Heyd, E. Brothers, K. N. Kudin, V. N. Staroverov, R. Kobayashi, J. Normand, K. Raghavachari, A. Rendell, J. C. Bu- 
rant, S. S. Iyengar, J. Tomasi, M. Cossi, N. Rega, J. M. Millam, M. Klene, J. E. Knox, J. B. Cross, V. Bakken, C. Adamo, J. Jaramillo, R. Gomperts, R. E. Stratmann, O. Yazyev, A. J. Austin, R. Cammi, C. Pomelli, J. W. Ochterski, R. L. Martin, K. Morokuma, V. G. Zakrzewski, G. A. Voth, P. Salvador, J. J. Dannenberg, S. Dapprich, A. D. Daniels, O. Farkas, J. B. Foresman, J. V. Ortiz, J. Cioslowski, and D. J. Fox, Gaussian 09, Revision A.02; Gaussian, Inc.: Wallingford, CT, 2009.

39. R. Krishnan, J. S. Binkley, R. Seeger, and J. A. Pople, J. Chem. Phys. 72 (1980) 650.

40. A. D. McLean and G. S. Chandler, J. Chem. Phys. 72 (1980) 5639-5648.

41. M. J. Frisch, J. A. Pople, and J. S. Binkley, J. Chem. Phys. 80 (1984) 3265

42. T. Clark, J. Chandrasekhar, G. W. Spitznagel, and P. V. R. Schleyer, J. Comput. Chem. 4 (1983) 294-301.

43. P. M. W. Gill, B. G. Johnson, J. A. Pople, and M. Frisch, J. Chem. Phys. Lett. 197 (1992) 499-505.

44. C. T. Lee, W. T. Yang, and R. G. Parr, Phys. Rev. B 37 (1988) 785-789.

45. A. Gomez-Zavaglia, A. Kaczor, D. Coelho, M. L. S. Cristiano, and R. Fausto, J. Mol. Struct. 919 (2009) 271-276.

46. A. Gómez-Zavaglia, A. Kaczor, R. Almeida, M. D. L. S. Cristiano, and R. Fausto, J. Phys. Chem. A 112 (2008) 1762-1772.

47. A. Kaczor, R. Almeida, A. Gomez-Zavaglia, M. D. S. Cristiano, and R. Fausto, J. Mol. Struct. 876 (2008) 77-85.

48. A. Borba, A. Gómez-Zavaglia, P. N. N. L. Simões, and R.
Fausto, J. Phys. Chem. A 109 (2005) 3578-3586.

49. A. Gomez-Zavaglia, A. Kaczor, R. Almeida, M. L. S. Cristiano, M. E. S. Eusebio, T. M. R. Maria, P. Mobili, and R. Fausto, J. Phys. Chem. A 113 (2009) 3517-3522.

50. P. Pulay, J. Comput. Chem. 3 (1982) 556-560.

51. A. E. Reed, R. B. Weinstock, and F. Weinhold, J. Chem. Phys. 83 (1985) 735.

52. J. Tomasi, B. Mennucci, and R. Cammi, Chem. Rev. 105 (2005) 2999-3093.

53. G. Scalmani and M. J. Frisch, J. Chem. Phys. 132 (2010) 114110.

54. R. A. M. O'Ferrall, J. Chem. Soc. B Phys. Org. 1970274

55. B. D. Song and W. P. Jencks, J. Am. Chem. Soc. 111 (1989) 8470-8479.

56. N. E. Hall and B. J. Smith, J. Phys. Chem. A 102 (1998) 3985-3990.

57. N. E. Hall and B. J. Smith, J. Phys. Chem. A 102 (1998) 4930-4938.

58. M. Mugnai, G. Cardini, V. Schettino, and C. Nielsen, J. Mol. Phys. 105 (2007) 2203-2210.

59. M. Sato, H. Yamataka, Y. Komeiji, and Y. Mochizuki, Chemistry 18 (2012) 9714-21.

60. S. Wolfe, C.-K. Kim, K. Yang, N. Weinberg, and Z. Shi, J. Am. Chem. Soc. 117 (1995) 4240-4260.

61. G. S. Hammond, J. Am. Chem. Soc. 77 (1955) 334-338.

62. J. E. Leffler, Science 117 (1953) 340-341. 


\title{
Supporting Information
}

\section{Investigations into the mechanism of solvolysisof \\ 3-aryloxybenzisothiazoles.}

\author{
AminIsmael, ${ }^{1,2}$ David J.P. Gago, ${ }^{1}$ Lília I.L. Cabral, ${ }^{1}$ Rui Fausto ${ }^{2}$ and \\ Maria Lurdes. S. Cristiano ${ }^{1 *}$ \\ ${ }^{1}$ CCMAR and Department of Chemistry and Pharmacy, FCT, University of Algarve, Campus \\ de Gambelas, Faro 8005-039, Portugal. \\ ${ }^{2}$ CQC, Department of Chemistry, University of Coimbra, P-3004-535Coimbra, Portugal.
}

\section{Index}

Table S1. Structure of the aryloxysaccharins investigated, optimized at the O3LYP/6-31++G(d,p) level of theory, with Cartesian coordinates and NPA charges.*

Table S2. Structure of the 2-cyanobenzene sulfone cation, optimized at the O3LYP/6-31++G(d,p) level of theory, with Cartesian coordinates and NPA charges.*

Table S3. Calculated Cartesian coordinates $(\AA)$ for each of the considered structures ....... 
Table S1. Structure of the aryloxysaccharins investigated, optimized at the O3LYP/6-31++G(d,p) level of theory, with Cartesian coordinates and NPA charges.*
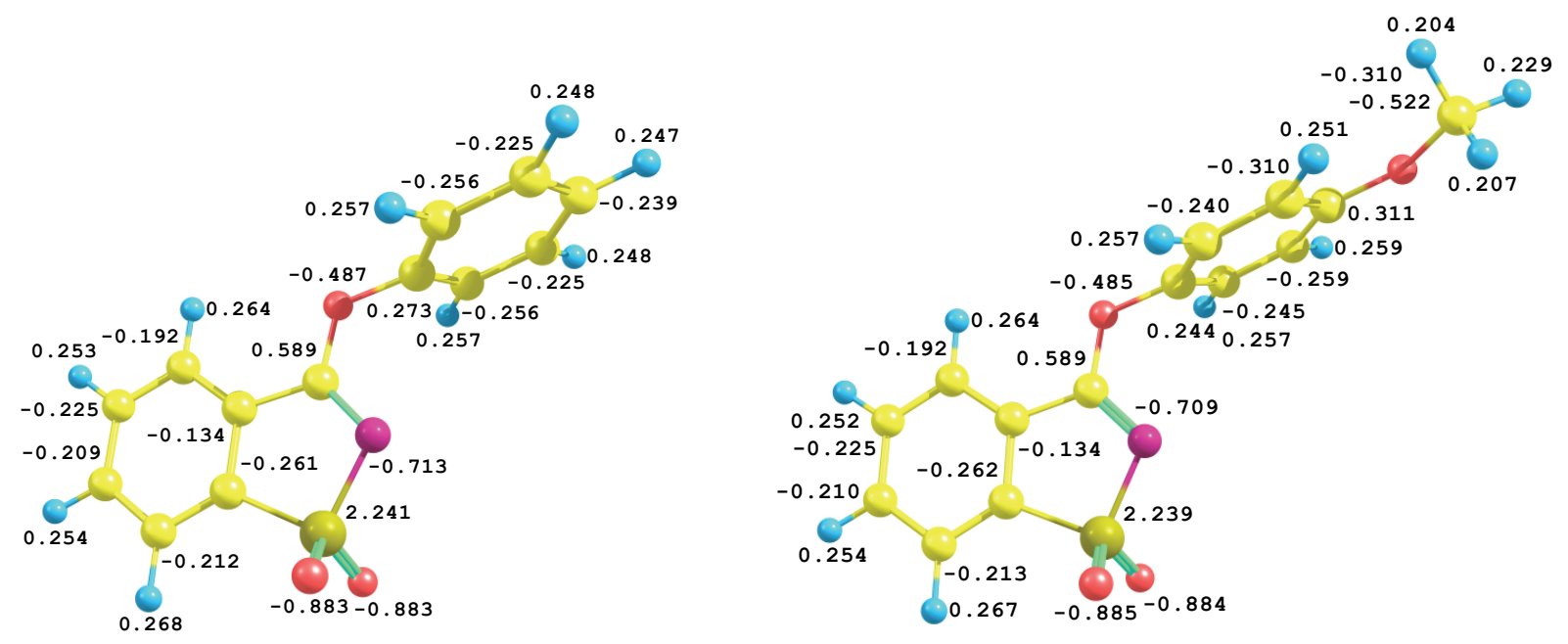

\begin{tabular}{|c|c|c|c|c|c|c|c|c|c|}
\hline \multirow{2}{*}{$\begin{array}{l}\text { 6a } \\
\text { Atom }\end{array}$} & \multicolumn{9}{|c|}{$6 b$} \\
\hline & $\mathbf{X}$ & $\mathbf{Y}$ & $\mathbf{Z}$ & NPA & Atom & $\mathbf{X}$ & $\mathbf{Y}$ & $\mathbf{Z}$ & NPA \\
\hline $\mathrm{C}$ & 2.31741200 & 0.12375800 & 0.00000000 & -0.26118 & $\mathrm{C}$ & -3.03499000 & 0.19760500 & -0.04183700 & 0.26154 \\
\hline $\mathrm{C}$ & 1.36618100 & -0.89427100 & 0.00000000 & -0.13427 & $\mathrm{C}$ & -2.13574800 & -0.86648800 & -0.05192500 & 0.13392 \\
\hline $\mathrm{C}$ & 1.76249000 & -2.23162900 & -0.00000200 & -0.19195 & $\mathrm{C}$ & -2.59814800 & -2.18096800 & -0.11720100 & 0.19214 \\
\hline $\mathrm{C}$ & 3.13371400 & -2.50930300 & -0.00000200 & -0.22482 & $\mathrm{C}$ & -3.98073600 & -2.38829100 & -0.17183100 & 0.22528 \\
\hline $\mathrm{C}$ & 4.07859800 & -1.47518100 & -0.00000100 & -0.20914 & $\mathrm{C}$ & -4.87263700 & -1.30818300 & -0.16128300 & 0.20978 \\
\hline $\mathrm{C}$ & 3.67958000 & -0.13168900 & 0.00000000 & -0.21250 & $\mathrm{C}$ & -4.40734400 & 0.01218300 & -0.09514500 & 0.21287 \\
\hline $\mathrm{S}$ & 1.42653000 & 1.69328700 & 0.00000200 & 2.24071 & $\mathrm{~S}$ & -2.06812800 & 1.71833700 & 0.05229400 & 2.23892 \\
\hline $\mathrm{N}$ & -0.12524000 & 0.98107400 & 0.00000100 & -0.71330 & $\mathrm{~N}$ & -0.55538700 & 0.93010900 & 0.07503600 & -0.70851 \\
\hline $\mathrm{C}$ & 0.00903100 & -0.30125000 & 0.00000000 & 0.58925 & $\mathrm{C}$ & -0.75117000 & -0.34350700 & 0.01707400 & 0.58937 \\
\hline $\mathrm{H}$ & 1.02730000 & -3.02946500 & -0.00000300 & 0.26389 & $\mathrm{H}$ & -1.90396800 & -3.01471400 & -0.12448500 & 0.26382 \\
\hline $\mathrm{H}$ & 3.47083700 & -3.54160100 & -0.00000300 & 0.25288 & $\mathrm{H}$ & -4.36839200 & -3.40144200 & -0.22264800 & 0.25249 \\
\hline $\mathrm{H}$ & 5.13770500 & -1.71647600 & -0.00000100 & 0.25393 & $\mathrm{H}$ & -5.94184500 & -1.49500300 & -0.20419100 & 0.25353 \\
\hline $\mathrm{H}$ & 4.40749700 & 0.67317700 & 0.00000000 & 0.26769 & $\mathrm{H}$ & -5.09397500 & 0.85252300 & -0.08597500 & 0.26734 \\
\hline $\mathrm{O}$ & 1.62806400 & 2.39295000 & 1.26675800 & -0.88251 & $\mathrm{O}$ & -2.19024800 & 2.47721600 & -1.19078200 & -0.88492 \\
\hline $\mathrm{O}$ & 1.62806400 & 2.39295100 & -1.26675500 & -0.88251 & $\mathrm{O}$ & -2.28179100 & 2.37751300 & 1.33875600 & -0.88398 \\
\hline $\mathrm{O}$ & -1.01209000 & -1.16394200 & 0.00000000 & -0.48712 & $\mathrm{O}$ & 0.22454100 & -1.25584500 & 0.01364600 & -0.48462 \\
\hline $\mathrm{C}$ & -2.33282300 & -0.67298900 & 0.00000000 & 0.27335 & $\mathrm{C}$ & 1.56750900 & -0.83148000 & 0.08235500 & 0.24395 \\
\hline $\mathrm{C}$ & -2.97891000 & -0.48461700 & -1.21780200 & -0.25620 & $\mathrm{C}$ & 2.19772400 & -0.78468300 & 1.32460200 & -0.24458 \\
\hline $\mathrm{C}$ & -2.97891300 & -0.48462700 & 1.21780000 & -0.25620 & $\mathrm{C}$ & 2.26118200 & -0.56185000 & -1.08821100 & -0.24006 \\
\hline $\mathrm{C}$ & -4.31608500 & -0.08094100 & -1.21005700 & -0.22458 & $\mathrm{C}$ & 3.54515400 & -0.45019900 & 1.38985700 & -0.25943 \\
\hline $\mathrm{H}$ & -2.44358200 & -0.64523100 & -2.14778900 & 0.25713 & $\mathrm{H}$ & 1.63762300 & -1.00315400 & 2.22792900 & 0.25723 \\
\hline $\mathrm{C}$ & -4.31608800 & -0.08095100 & 1.21005600 & -0.22458 & $\mathrm{C}$ & 3.61669600 & -0.22346400 & -1.02529500 & -0.30985 \\
\hline $\mathrm{H}$ & -2.44358700 & -0.64524900 & 2.14778900 & 0.25713 & $\mathrm{H}$ & 1.75285800 & -0.60700800 & -2.04580200 & 0.25654 \\
\hline $\mathrm{C}$ & -4.98524800 & 0.12121100 & 0.00000000 & -0.23914 & $\mathrm{C}$ & 4.26464000 & -0.16497300 & 0.21675800 & 0.31077 \\
\hline $\mathrm{H}$ & -4.83251400 & 0.07441500 & -2.15283500 & 0.24837 & $\mathrm{H}$ & 4.05987300 & -0.40228500 & 2.34373500 & 0.25875 \\
\hline $\mathrm{H}$ & -4.83252000 & 0.07439600 & 2.15283500 & 0.24837 & $\mathrm{H}$ & 4.14411300 & -0.00998900 & -1.94660900 & 0.25065 \\
\hline \multirow[t]{5}{*}{$\mathrm{H}$} & -6.02488200 & 0.43512200 & 0.00000000 & 0.24728 & $\mathrm{O}$ & 5.57653000 & 0.15024400 & 0.39703600 & -0.52245 \\
\hline & & & & & $\mathrm{C}$ & 6.37202500 & 0.46593900 & -0.73428300 & -0.31030 \\
\hline & & & & & $\mathrm{H}$ & 5.98925300 & 1.34754600 & -1.26328100 & 0.20699 \\
\hline & & & & & $\mathrm{H}$ & 7.36591400 & 0.68670900 & -0.34197000 & 0.22949 \\
\hline & & & & & $\mathrm{H}$ & 6.43911800 & -0.38021100 & -1.42970600 & 0.20440 \\
\hline
\end{tabular}




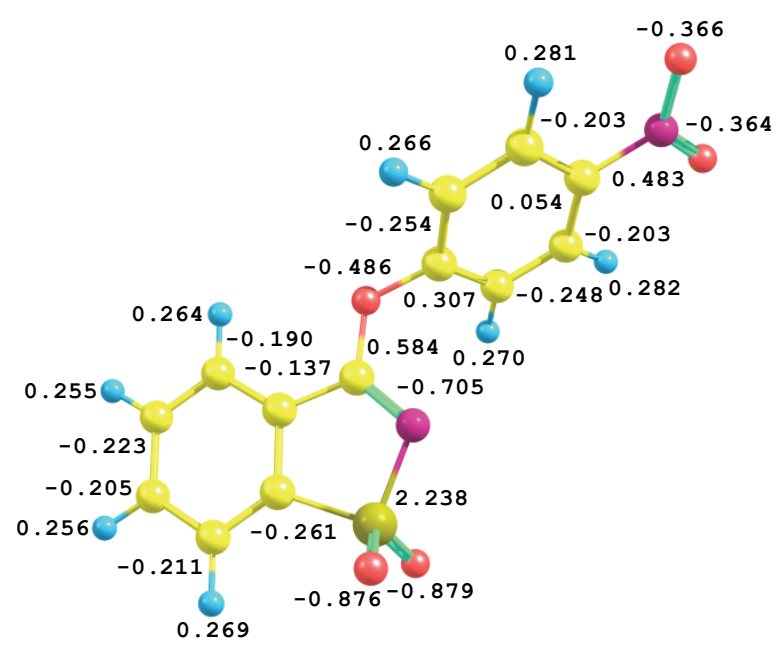

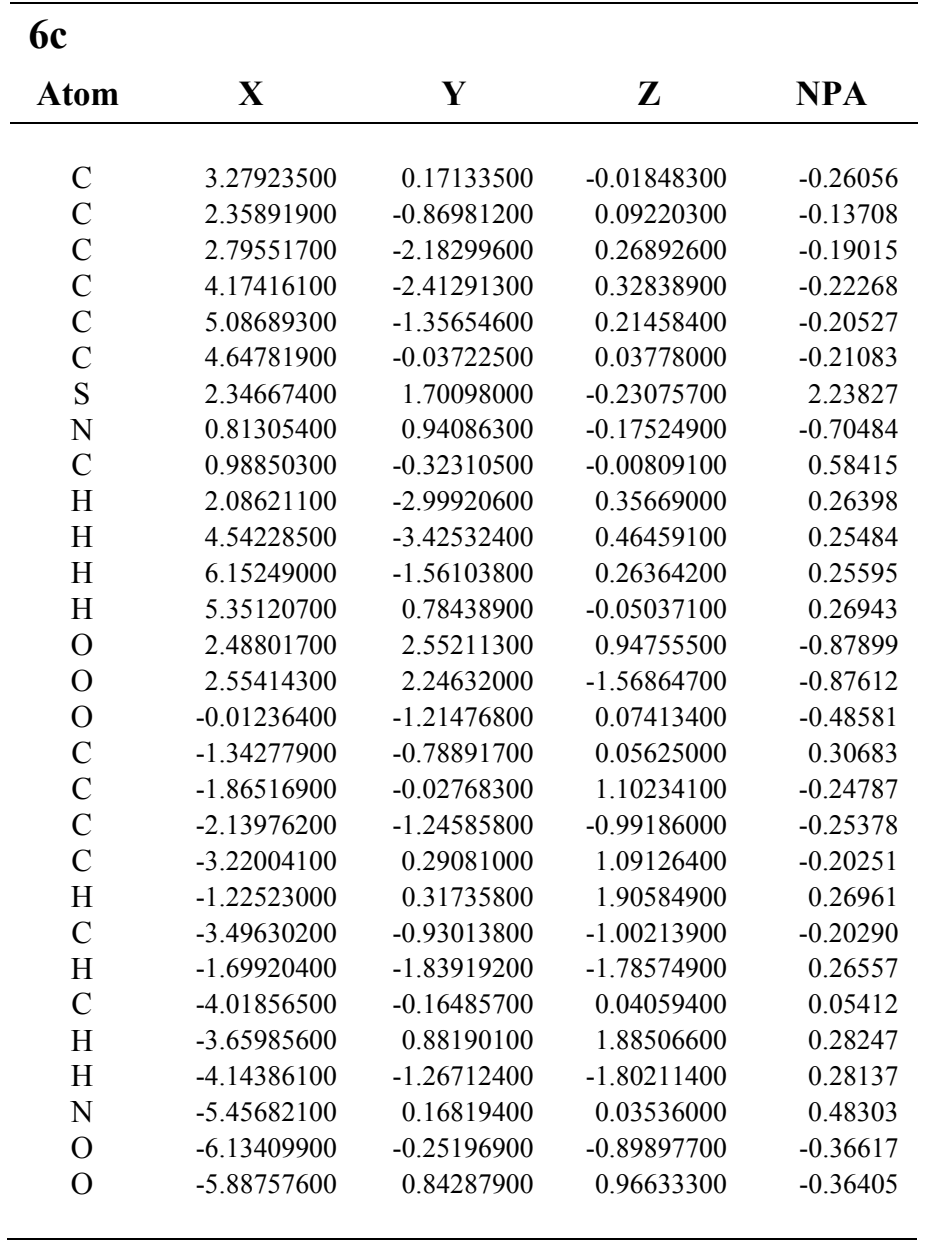


Table S2. Structure of the 2-cyanobenzene sulfone cation, optimized at the O3LYP/6-31++G(d,p) level of theory, with Cartesian coordinates and NPA charges.*

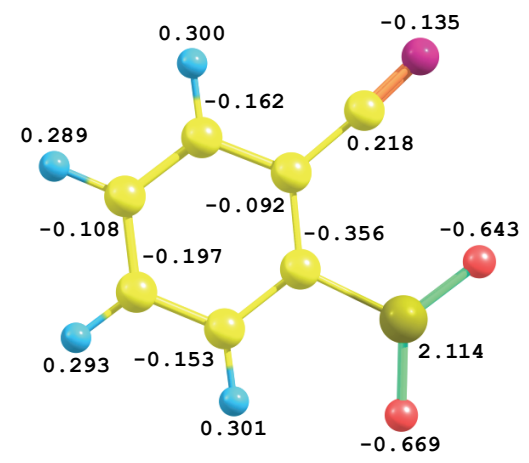

\begin{tabular}{crrrr}
\hline $\mathbf{1 2}$ & & & & \\
Atom & $\mathbf{X}$ & $\mathbf{Y}$ & $\mathbf{Z}$ & \multicolumn{1}{c}{$\mathbf{N P A}$} \\
\hline & & & & \\
$\mathrm{C}$ & -0.10807900 & -0.40527500 & 0.00002500 & -0.35553 \\
$\mathrm{C}$ & -0.78344700 & 0.85889800 & -0.00003800 & -0.09173 \\
$\mathrm{C}$ & -2.18326200 & 0.82286800 & -0.00007200 & -0.16239 \\
$\mathrm{C}$ & -2.87411500 & -0.39431900 & -0.00003700 & -0.10790 \\
$\mathrm{C}$ & -2.19051200 & -1.61818000 & 0.00004200 & -0.19731 \\
$\mathrm{C}$ & -0.80355800 & -1.63741500 & 0.00006500 & -0.15338 \\
$\mathrm{~S}$ & 1.61652500 & -0.51086300 & -0.00001500 & 2.11423 \\
$\mathrm{~N}$ & 0.32638200 & 3.20109700 & 0.00014800 & -0.13451 \\
$\mathrm{C}$ & -0.13641600 & 2.12941700 & -0.00003600 & 0.21841 \\
$\mathrm{H}$ & -2.72494200 & 1.76299400 & -0.00012000 & 0.29975 \\
$\mathrm{H}$ & -3.96033500 & -0.38317100 & -0.00007100 & 0.28904 \\
$\mathrm{H}$ & -2.73686300 & -2.55587400 & 0.00008000 & 0.29297 \\
$\mathrm{H}$ & -0.26297600 & -2.57732900 & 0.00012600 & 0.30068 \\
$\mathrm{O}$ & 2.14696400 & -1.85305500 & 0.00001600 & -0.66917 \\
$\mathrm{O}$ & 2.35458300 & 0.72599800 & -0.00007900 & -0.64317 \\
& & & & \\
\hline
\end{tabular}

*The charge distribution has been analyzed using the Natural Population Analysis (NPA), see: Reed, A. E.; Weinstock, R. B.; Weinhold, F. J. Chem. Phys.1985, 83, 735.

Color codes: light yellow $-\mathrm{C}$, blue $-\mathrm{H}$, red $-\mathrm{O}$, pink $-\mathrm{N}$, dark yellow $-\mathrm{S}$;

Chemcraft software (http://www.chemcraftprog.com) was used to produce structures shown in Table S1 and Table S2. 
Table S3. Calculated Cartesian coordinates $(\AA)$ for each of the considered structures

O3LYP/6-31++G(d,p)

O3LYP/6-311++G(3df,3pd)

\begin{tabular}{|c|c|c|c|c|c|c|c|}
\hline \multicolumn{8}{|l|}{$6 \mathbf{a}$} \\
\hline Atom & $\mathbf{X}$ & $\mathbf{Y}$ & $\mathbf{Z}$ & Atom & $\mathbf{X}$ & $\mathbf{Y}$ & $\mathbf{Z}$ \\
\hline $\mathrm{C}$ & 2.31741200 & 0.12375800 & 0.00000000 & $\mathrm{C}$ & 2.30429600 & 0.13780700 & -0.00000300 \\
\hline $\mathrm{C}$ & 1.36618100 & -0.89427100 & 0.00000000 & $\mathrm{C}$ & 1.37026900 & -0.88949300 & -0.00000100 \\
\hline $\mathrm{C}$ & 1.76249000 & -2.23162900 & -0.00000200 & $\mathrm{C}$ & 1.77902300 & -2.21653200 & -0.00000200 \\
\hline $\mathrm{C}$ & 3.13371400 & -2.50930300 & -0.00000200 & $\mathrm{C}$ & 3.14690100 & -2.47916200 & -0.00000400 \\
\hline $\mathrm{C}$ & 4.07859800 & -1.47518100 & -0.00000100 & $\mathrm{C}$ & 4.07535800 & -1.43880400 & -0.00000600 \\
\hline $\mathrm{C}$ & 3.67958000 & -0.13168900 & 0.00000000 & $\mathrm{C}$ & 3.66345700 & -0.10590600 & -0.00000500 \\
\hline $\mathrm{S}$ & 1.42653000 & 1.69328700 & 0.00000200 & $\mathrm{~S}$ & 1.40168500 & 1.67783300 & 0.00000400 \\
\hline $\mathrm{N}$ & -0.12524000 & 0.98107400 & 0.00000100 & $\mathrm{~N}$ & -0.11151000 & 0.96912100 & 0.00000500 \\
\hline $\mathrm{C}$ & 0.00903100 & -0.30125000 & 0.00000000 & $\mathrm{C}$ & 0.01247100 & -0.30774700 & 0.00000300 \\
\hline $\mathrm{H}$ & 1.02730000 & -3.02946500 & -0.00000300 & $\mathrm{H}$ & 1.05516000 & -3.02092300 & -0.00000100 \\
\hline $\mathrm{H}$ & 3.47083700 & -3.54160100 & -0.00000300 & $\mathrm{H}$ & 3.49459100 & -3.50492700 & -0.00000400 \\
\hline $\mathrm{H}$ & 5.13770500 & -1.71647600 & -0.00000100 & $\mathrm{H}$ & 5.13428400 & -1.66807800 & -0.00000700 \\
\hline $\mathrm{H}$ & 4.40749700 & 0.67317700 & 0.00000000 & $\mathrm{H}$ & 4.38190400 & 0.70346400 & -0.00000700 \\
\hline $\mathrm{O}$ & 1.62806400 & 2.39295000 & 1.26675800 & $\mathrm{O}$ & 1.59673000 & 2.37008900 & 1.24012900 \\
\hline $\mathrm{O}$ & 1.62806400 & 2.39295100 & -1.26675500 & $\mathrm{O}$ & 1.59672200 & 2.37009900 & -1.24011700 \\
\hline $\mathrm{O}$ & -1.01209000 & -1.16394200 & 0.00000000 & $\mathrm{O}$ & -1.00434300 & -1.16482300 & 0.00000300 \\
\hline $\mathrm{C}$ & -2.33282300 & -0.67298900 & 0.00000000 & $\mathrm{C}$ & -2.32154400 & -0.67600800 & 0.00000100 \\
\hline $\mathrm{C}$ & -2.97891000 & -0.48461700 & -1.21780200 & $\mathrm{C}$ & -2.96529300 & -0.48671300 & -1.21194400 \\
\hline $\mathrm{C}$ & -2.97891300 & -0.48462700 & 1.21780000 & $\mathrm{C}$ & -2.96530300 & -0.48673000 & 1.21194300 \\
\hline $\mathrm{C}$ & -4.31608500 & -0.08094100 & -1.21005700 & $\mathrm{C}$ & -4.29649900 & -0.08520600 & -1.20389100 \\
\hline $\mathrm{H}$ & -2.44358200 & -0.64523100 & -2.14778900 & $\mathrm{H}$ & -2.43165500 & -0.64665700 & -2.13977000 \\
\hline $\mathrm{C}$ & -4.31608800 & -0.08095100 & 1.21005600 & $\mathrm{C}$ & -4.29651000 & -0.08522300 & 1.20388400 \\
\hline $\mathrm{H}$ & -2.44358700 & -0.64524900 & 2.14778900 & $\mathrm{H}$ & -2.43167500 & -0.64668700 & 2.13977200 \\
\hline $\mathrm{C}$ & -4.98524800 & 0.12121100 & 0.00000000 & $\mathrm{C}$ & -4.96323000 & 0.11663200 & -0.00000500 \\
\hline $\mathrm{H}$ & -4.83251400 & 0.07441500 & -2.15283500 & $\mathrm{H}$ & -4.81112100 & 0.07018200 & -2.14441600 \\
\hline $\mathrm{H}$ & -4.83252000 & 0.07439600 & 2.15283500 & $\mathrm{H}$ & -4.81114000 & 0.07015100 & 2.14440600 \\
\hline $\mathrm{H}$ & -6.02488200 & 0.43512200 & 0.00000000 & $\mathrm{H}$ & -5.99998400 & 0.42988600 & -0.00000800 \\
\hline
\end{tabular}

\section{6b}

\begin{tabular}{|c|c|c|c|c|c|c|c|}
\hline Atom & $\mathbf{X}$ & $\mathbf{Y}$ & $\mathbf{Z}$ & Atom & $\mathbf{X}$ & $\mathbf{Y}$ & $\mathbf{Z}$ \\
\hline $\mathrm{C}$ & -3.03499000 & 0.19760500 & -0.04183700 & $\mathrm{C}$ & -3.01793100 & 0.21085400 & -0.04124300 \\
\hline $\mathrm{C}$ & -2.13574800 & -0.86648800 & -0.05192500 & $\mathrm{C}$ & -2.13655100 & -0.86179200 & -0.05186200 \\
\hline $\mathrm{C}$ & -2.59814800 & -2.18096800 & -0.11720100 & $\mathrm{C}$ & -2.61130600 & -2.16521900 & -0.11770800 \\
\hline $\mathrm{C}$ & -3.98073600 & -2.38829100 & -0.17183100 & $\mathrm{C}$ & -3.98981000 & -2.35723800 & -0.17276600 \\
\hline $\mathrm{C}$ & -4.87263700 & -1.30818300 & -0.16128300 & $\mathrm{C}$ & -4.86468400 & -1.27147800 & -0.16208000 \\
\hline $\mathrm{C}$ & -4.40734400 & 0.01218300 & -0.09514500 & $\mathrm{C}$ & -4.38665700 & 0.03748600 & -0.09539000 \\
\hline $\mathrm{S}$ & -2.06812800 & 1.71833700 & 0.05229400 & $\mathrm{~S}$ & -2.04098500 & 1.70146700 & 0.05294200 \\
\hline $\mathrm{N}$ & -0.55538700 & 0.93010900 & 0.07503600 & $\mathrm{~N}$ & -0.56651700 & 0.91857500 & 0.07451200 \\
\hline $\mathrm{C}$ & -0.75117000 & -0.34350700 & 0.01707400 & $\mathrm{C}$ & -0.75173600 & -0.35014800 & 0.01687300 \\
\hline $\mathrm{H}$ & -1.90396800 & -3.01471400 & -0.12448500 & $\mathrm{H}$ & -1.92898900 & -3.00512700 & -0.12525900 \\
\hline $\mathrm{H}$ & -4.36839200 & -3.40144200 & -0.22264800 & $\mathrm{H}$ & -4.38793200 & -3.36322300 & -0.22411100 \\
\hline $\mathrm{H}$ & -5.94184500 & -1.49500300 & -0.20419100 & $\mathrm{H}$ & -5.93312400 & -1.44601700 & -0.20553600 \\
\hline $\mathrm{H}$ & -5.09397500 & 0.85252300 & -0.08597500 & $\mathrm{H}$ & -5.06336400 & 0.88203800 & -0.08618400 \\
\hline $\mathrm{O}$ & -2.19024800 & 2.47721600 & -1.19078200 & $\mathrm{O}$ & -2.15783700 & 2.45228500 & -1.16317600 \\
\hline $\mathrm{O}$ & -2.28179100 & 2.37751300 & 1.33875600 & $\mathrm{O}$ & -2.24774000 & 2.35338300 & 1.31305500 \\
\hline $\mathrm{O}$ & 0.22454100 & -1.25584500 & 0.01364600 & $\mathrm{O}$ & 0.21977500 & -1.25673300 & 0.01383600 \\
\hline $\mathrm{C}$ & 1.56750900 & -0.83148000 & 0.08235500 & $\mathrm{C}$ & 1.55936800 & -0.83435000 & 0.08279100 \\
\hline $\mathrm{C}$ & 2.19772400 & -0.78468300 & 1.32460200 & $\mathrm{C}$ & 2.18698300 & -0.78486000 & 1.31927400 \\
\hline $\mathrm{C}$ & 2.26118200 & -0.56185000 & -1.08821100 & $\mathrm{C}$ & 2.25112800 & -0.56473600 & -1.08141500 \\
\hline $\mathrm{C}$ & 3.54515400 & -0.45019900 & 1.38985700 & $\mathrm{C}$ & 3.52806300 & -0.45054700 & 1.38447700 \\
\hline $\mathrm{H}$ & 1.63762300 & -1.00315400 & 2.22792900 & $\mathrm{H}$ & 1.62832900 & -1.00191000 & 2.22054000 \\
\hline $\mathrm{C}$ & 3.61669600 & -0.22346400 & -1.02529500 & $\mathrm{C}$ & 3.60045800 & -0.22716700 & -1.01796500 \\
\hline $\mathrm{H}$ & 1.75285800 & -0.60700800 & -2.04580200 & $\mathrm{H}$ & 1.74496100 & -0.61014200 & -2.03702000 \\
\hline $\mathrm{C}$ & 4.26464000 & -0.16497300 & 0.21675800 & $\mathrm{C}$ & 4.24715500 & -0.16664300 & 0.21783000 \\
\hline $\mathrm{H}$ & 4.05987300 & -0.40228500 & 2.34373500 & $\mathrm{H}$ & 4.03932600 & -0.40151700 & 2.33716000 \\
\hline $\mathrm{H}$ & 4.14411300 & -0.00998900 & -1.94660900 & $\mathrm{H}$ & 4.12709100 & -0.01412200 & -1.93648000 \\
\hline
\end{tabular}




$\begin{array}{rrrrrrrr}\mathrm{O} & 5.57653000 & 0.15024400 & 0.39703600 & \mathrm{O} & 5.55384200 & 0.14938800 & 0.39415800 \\ \mathrm{C} & 6.37202500 & 0.46593900 & -0.73428300 & \mathrm{C} & 6.34322200 & 0.46423100 & -0.73562500 \\ \mathrm{H} & 5.98925300 & 1.34754600 & -1.26328100 & \mathrm{H} & 5.95824800 & 1.34133600 & -1.26470600 \\ \mathrm{H} & 7.36591400 & 0.68670900 & -0.34197000 & \mathrm{H} & 7.33664800 & 0.68778700 & -0.35160300 \\ \mathrm{H} & 6.43911800 & -0.38021100 & -1.42970600 & \mathrm{H} & 6.40964900 & -0.37954100 & -1.42958300\end{array}$

$6 c$

\begin{tabular}{|c|c|c|c|c|c|c|c|}
\hline Atom & $\mathbf{X}$ & $\mathbf{Y}$ & $\mathbf{Z}$ & Atom & $\mathbf{X}$ & $\mathbf{Y}$ & $\mathbf{Z}$ \\
\hline $\mathrm{C}$ & 3.27923500 & 0.17133500 & -0.01848300 & $\mathrm{C}$ & 3.26555200 & 0.17895400 & -0.01944500 \\
\hline $\mathrm{C}$ & 2.35891900 & -0.86981200 & 0.09220300 & $\mathrm{C}$ & 2.35686000 & -0.86551300 & 0.09419100 \\
\hline $\mathrm{C}$ & 2.79551700 & -2.18299600 & 0.26892600 & $\mathrm{C}$ & 2.79821400 & -2.16941600 & 0.27838200 \\
\hline $\mathrm{C}$ & 4.17416100 & -2.41291300 & 0.32838900 & $\mathrm{C}$ & 4.17164800 & -2.39108900 & 0.34367600 \\
\hline $\mathrm{C}$ & 5.08689300 & -1.35654600 & 0.21458400 & $\mathrm{C}$ & 5.07365000 & -1.33412500 & 0.22788700 \\
\hline $\mathrm{C}$ & 4.64781900 & -0.03722500 & 0.03778000 & $\mathrm{C}$ & 4.62946400 & -0.02437600 & 0.04349600 \\
\hline S & 2.34667400 & 1.70098000 & -0.23075700 & $\mathrm{~S}$ & 2.33052500 & 1.68237100 & -0.23912700 \\
\hline $\mathrm{N}$ & 0.81305400 & 0.94086300 & -0.17524900 & $\mathrm{~N}$ & 0.83142700 & 0.93511400 & -0.18747400 \\
\hline $\mathrm{C}$ & 0.98850300 & -0.32310500 & -0.00809100 & $\mathrm{C}$ & 0.98909300 & -0.32374500 & -0.01334700 \\
\hline $\mathrm{H}$ & 2.08621100 & -2.99920600 & 0.35669000 & $\mathrm{H}$ & 2.09576700 & -2.98766900 & 0.36783900 \\
\hline $\mathrm{H}$ & 4.54228500 & -3.42532400 & 0.46459100 & $\mathrm{H}$ & 4.54439900 & -3.39786200 & 0.48622300 \\
\hline $\mathrm{H}$ & 6.15249000 & -1.56103800 & 0.26364200 & $\mathrm{H}$ & 6.13746400 & -1.53182700 & 0.28184500 \\
\hline $\mathrm{H}$ & 5.35120700 & 0.78438900 & -0.05037100 & $\mathrm{H}$ & 5.32772800 & 0.79753800 & -0.04603300 \\
\hline $\mathrm{O}$ & 2.48801700 & 2.55211300 & 0.94755500 & $\mathrm{O}$ & 2.46544400 & 2.52694200 & 0.91073700 \\
\hline $\mathrm{O}$ & 2.55414300 & 2.24632000 & -1.56864700 & $\mathrm{O}$ & 2.54056800 & 2.21740300 & -1.55096600 \\
\hline $\mathrm{O}$ & -0.01236400 & -1.21476800 & 0.07413400 & $\mathrm{O}$ & -0.01155600 & -1.20544000 & 0.06819700 \\
\hline $\mathrm{C}$ & -1.34277900 & -0.78891700 & 0.05625000 & $\mathrm{C}$ & -1.33827400 & -0.78220600 & 0.05201900 \\
\hline $\mathrm{C}$ & -1.86516900 & -0.02768300 & 1.10234100 & $\mathrm{C}$ & -1.84954600 & 0.01200800 & 1.07088600 \\
\hline $\mathrm{C}$ & -2.13976200 & -1.24585800 & -0.99186000 & $\mathrm{C}$ & -2.14412200 & -1.27493600 & -0.96493100 \\
\hline $\mathrm{C}$ & -3.22004100 & 0.29081000 & 1.09126400 & $\mathrm{C}$ & -3.19924800 & 0.32629000 & 1.06317300 \\
\hline $\mathrm{H}$ & -1.22523000 & 0.31735800 & 1.90584900 & $\mathrm{H}$ & -1.20418100 & 0.38490700 & 1.85351600 \\
\hline $\mathrm{C}$ & -3.49630200 & -0.93013800 & -1.00213900 & $\mathrm{C}$ & -3.49491300 & -0.96145200 & -0.97218300 \\
\hline $\mathrm{H}$ & -1.69920400 & -1.83919200 & -1.78574900 & $\mathrm{H}$ & -1.71309000 & -1.89519200 & -1.73949300 \\
\hline $\mathrm{C}$ & -4.01856500 & -0.16485700 & 0.04059400 & $\mathrm{C}$ & -4.00495700 & -0.16387500 & 0.04299100 \\
\hline $\mathrm{H}$ & -3.65985600 & 0.88190100 & 1.88506600 & $\mathrm{H}$ & -3.63091600 & 0.94236200 & 1.83816700 \\
\hline $\mathrm{H}$ & -4.14386100 & -1.26712400 & -1.80211400 & $\mathrm{H}$ & -4.14941400 & -1.32598900 & -1.75006700 \\
\hline $\mathrm{N}$ & -5.45682100 & 0.16819400 & 0.03536000 & $\mathrm{~N}$ & -5.44456200 & 0.16828200 & 0.04121600 \\
\hline $\mathrm{O}$ & -6.13409900 & -0.25196900 & -0.89897700 & $\mathrm{O}$ & -6.12440200 & -0.28276800 & -0.86385700 \\
\hline $\mathrm{O}$ & -5.88757600 & 0.84287900 & 0.96633300 & $\mathrm{O}$ & -5.86064600 & 0.87047700 & 0.94552400 \\
\hline
\end{tabular}

\section{2}

\begin{tabular}{ccrrrrrr} 
Attom & $\mathbf{X}$ & $\mathbf{Y}$ & $\mathbf{Z}$ & Atom & $\mathbf{X}$ & $\mathbf{Y}$ & $\mathbf{Z}$ \\
\hline & & & & & & & \\
C & -0.10807900 & -0.40527500 & 0.00002500 & $\mathrm{C}$ & 0.09996700 & -0.40266700 & 0.00000200 \\
$\mathrm{C}$ & -0.78344700 & 0.85889800 & -0.00003800 & $\mathrm{C}$ & 0.77215400 & 0.85816900 & 0.00000200 \\
$\mathrm{C}$ & -2.18326200 & 0.82286800 & -0.00007200 & $\mathrm{C}$ & 2.16490800 & 0.82469800 & 0.00000700 \\
$\mathrm{C}$ & -2.87411500 & -0.39431900 & -0.00003700 & $\mathrm{C}$ & 2.85491400 & -0.38661800 & 0.00000300 \\
$\mathrm{C}$ & -2.19051200 & -1.61818000 & 0.00004200 & $\mathrm{C}$ & 2.17789100 & -1.60736200 & -0.00000500 \\
$\mathrm{C}$ & -0.80355800 & -1.63741500 & 0.00006500 & $\mathrm{C}$ & 0.79797400 & -1.62877300 & -0.000000400 \\
$\mathrm{~S}$ & 1.61652500 & -0.51086300 & -0.00001500 & $\mathrm{~S}$ & -1.59965500 & -0.51265900 & 0.00000300 \\
$\mathrm{~N}$ & 0.32638200 & 3.20109700 & 0.00014800 & $\mathrm{~N}$ & -0.33673000 & 3.18420100 & -0.000001100 \\
$\mathrm{C}$ & -0.13641600 & 2.12941700 & -0.00003600 & $\mathrm{C}$ & 0.12503200 & 2.12280400 & -0.00000400 \\
$\mathrm{H}$ & -2.72494200 & 1.76299400 & -0.00012000 & $\mathrm{H}$ & 2.70467700 & 1.76262600 & 0.000001200 \\
$\mathrm{H}$ & -3.96033500 & -0.38317100 & -0.00007100 & $\mathrm{H}$ & 3.93841900 & -0.37270000 & 0.00000800 \\
$\mathrm{H}$ & -2.73686300 & -2.55587400 & 0.000008000 & $\mathrm{H}$ & 2.72585900 & -2.54076700 & -0.000000800 \\
$\mathrm{H}$ & -0.26297600 & -2.57732900 & 0.00012600 & $\mathrm{H}$ & 0.25772200 & -2.56506800 & -0.00000500 \\
$\mathrm{O}$ & 2.14696400 & -1.85305500 & 0.00001600 & $\mathrm{O}$ & -2.12290500 & -1.82814700 & -0.000000700 \\
$\mathrm{O}$ & 2.35458300 & 0.72599800 & -0.00007900 & $\mathrm{O}$ & -2.33111000 & 0.69658900 & 0.00000900 \\
& & & & & & & \\
\hline
\end{tabular}

O3LYP/6-31++G(d,p)

7

Atom $\quad \mathrm{X}$

\section{$8 \mathbf{a}$}

Atom
$\mathbf{X}$

Y
Z 


$\begin{array}{lrrr}\mathrm{C} & 0.57586800 & 0.87288300 & 0.00000000 \\ \mathrm{C} & 0.82170200 & -0.49836800 & 0.00000000 \\ \mathrm{C} & 2.12863900 & -0.98260200 & 0.00000000 \\ \mathrm{C} & 3.17238700 & -0.05004200 & 0.00000000 \\ \mathrm{C} & 2.90999900 & 1.32628400 & 0.00000000 \\ \mathrm{C} & 1.59449600 & 1.81152100 & 0.00000000 \\ \mathrm{~S} & -1.21814900 & 1.10316900 & 0.00000000 \\ \mathrm{~N} & -1.57342300 & -0.57449000 & 0.00000000 \\ \mathrm{C} & -0.46378900 & -1.23703900 & 0.00000000 \\ \mathrm{H} & 2.32485900 & -2.04930900 & 0.00000000 \\ \mathrm{H} & 4.20075300 & -0.39752400 & 0.00000000 \\ \mathrm{H} & 3.73730500 & 2.02933700 & 0.00000000 \\ \mathrm{H} & 1.38505100 & 2.87592000 & 0.00000000 \\ \mathrm{O} & -1.65978700 & 1.68616200 & 1.26793700 \\ \mathrm{O} & -1.65978700 & 1.68616200 & -1.26793700 \\ \mathrm{O} & -0.40100900 & -2.56293300 & 0.00000000 \\ \mathrm{C} & -1.65978700 & -3.27580200 & 0.00000000 \\ \mathrm{H} & -2.23371500 & -3.01676100 & -0.89226400 \\ \mathrm{H} & -1.38863400 & -4.33031300 & 0.00000000 \\ \mathrm{H} & -2.23371500 & -3.01676100 & 0.89226400\end{array}$

$\begin{array}{lrrr}\mathrm{C} & 0.01946100 & -1.85960900 & 0.00000000 \\ \mathrm{C} & -1.19140000 & -1.16347400 & 0.00000000 \\ \mathrm{C} & -1.20794300 & 0.23363300 & 0.00000000 \\ \mathrm{C} & 0.00000000 & 0.94322300 & 0.00000000 \\ \mathrm{C} & 1.21844600 & 0.25321000 & 0.00000000 \\ \mathrm{C} & 1.21997700 & -1.14164400 & 0.00000000 \\ \mathrm{H} & 0.02803100 & -2.94526700 & 0.00000000 \\ \mathrm{H} & -2.13307700 & -1.70586700 & 0.00000000 \\ \mathrm{H} & -2.15557100 & 0.76844900 & 0.00000000 \\ \mathrm{H} & 2.14516900 & 0.81800500 & 0.00000000 \\ \mathrm{H} & 2.16935300 & -1.67048800 & 0.00000000 \\ \mathrm{O} & 0.05438400 & 2.30950700 & 0.00000000 \\ \mathrm{H} & -0.84022100 & 2.66707800 & 0.00000000\end{array}$

\begin{tabular}{|c|c|c|c|c|c|c|c|}
\hline \multicolumn{4}{|l|}{$8 b$} & \multicolumn{4}{|l|}{$8 c$} \\
\hline Atom & $\mathbf{X}$ & $\mathbf{Y}$ & $\mathbf{Z}$ & Atom & $\mathbf{X}$ & $\mathbf{Y}$ & $\mathbf{Z}$ \\
\hline $\mathrm{C}$ & -0.93120800 & 0.27536400 & -0.00001300 & & -0.69457700 & 0.00071800 & 0.00000000 \\
\hline $\mathrm{C}$ & -0.05348400 & 1.36872000 & -0.00000100 & & -0.00371500 & -1.21270200 & 0.00001300 \\
\hline $\mathrm{C}$ & 1.32462700 & 1.17017200 & 0.00000600 & & 1.38675400 & -1.20533100 & 0.00001500 \\
\hline $\mathrm{C}$ & 1.85304600 & -0.12790600 & 0.00000300 & & 2.08272100 & 0.01418000 & 0.00000000 \\
\hline $\mathrm{C}$ & 0.98233600 & -1.21793700 & -0.00000900 & & 1.37685000 & 1.22783900 & -0.00001600 \\
\hline $\mathrm{C}$ & -0.40226800 & -1.02217600 & -0.00001700 & & -0.01106600 & 1.22135700 & -0.00001300 \\
\hline $\mathrm{O}$ & -2.26468800 & 0.58483900 & -0.00002600 & & -0.55566000 & -2.14474500 & 0.00002200 \\
\hline $\mathrm{H}$ & -0.46636100 & 2.37247600 & 0.00000200 & & 1.93060800 & -2.14684400 & 0.00003000 \\
\hline $\mathrm{H}$ & 1.98839500 & 2.03251300 & 0.00001500 & & 1.93031300 & 2.16071300 & -0.00003000 \\
\hline $\mathrm{H}$ & 1.39235600 & -2.22292300 & -0.00001100 & & -0.57142900 & 2.14836200 & -0.00002200 \\
\hline $\mathrm{H}$ & -1.04811900 & -1.89202900 & -0.00002800 & & 3.43720500 & 0.08743600 & 0.00000000 \\
\hline $\mathrm{O}$ & 3.20037600 & -0.38638800 & 0.00001100 & & 3.81745400 & -0.79858600 & 0.00000400 \\
\hline $\mathrm{H}$ & 3.68503600 & 0.44566100 & 0.00001900 & & -2.16047900 & -0.00648100 & 0.00000000 \\
\hline $\mathrm{C}$ & -3.20859800 & -0.46929300 & 0.00003000 & & -2.73920000 & 1.07922400 & 0.00003700 \\
\hline $\mathrm{H}$ & -3.11732400 & -1.09790900 & -0.89568100 & & -2.72922200 & -1.09789700 & -0.00003700 \\
\hline $\mathrm{H}$ & -3.11726200 & -1.09786700 & 0.89576400 & & & & \\
\hline $\mathrm{H}$ & -4.18893500 & 0.01080500 & 0.00005200 & & & & \\
\hline
\end{tabular}

\begin{tabular}{|c|c|c|c|c|c|c|c|}
\hline \multicolumn{4}{|l|}{$9 \mathbf{a}$} & \multicolumn{4}{|l|}{$9 b$} \\
\hline Atom & $\mathbf{X}$ & $\mathbf{Y}$ & $\mathbf{Z}$ & Atom & $\mathbf{X}$ & $\mathbf{Y}$ & $\mathbf{Z}$ \\
\hline $\mathrm{C}$ & -2.18871300 & 0.34245300 & -0.25319600 & $\mathrm{C}$ & -2.75139900 & 0.53930200 & -0.27222900 \\
\hline $\mathrm{C}$ & -1.41371500 & -0.80862100 & -0.24635800 & $\mathrm{C}$ & -2.12505200 & -0.69796000 & -0.32468900 \\
\hline $\mathrm{C}$ & -1.92880700 & -1.98738900 & -0.78377400 & $\mathrm{C}$ & -2.75919400 & -1.76233300 & -0.96440100 \\
\hline $\mathrm{C}$ & -3.21963200 & -1.97334600 & -1.31810200 & $\mathrm{C}$ & -4.01484500 & -1.54869800 & -1.53867500 \\
\hline $\mathrm{C}$ & -3.98865900 & -0.80128600 & -1.31435400 & $\mathrm{C}$ & -4.63293100 & -0.29220100 & -1.47340900 \\
\hline $\mathrm{C}$ & -3.47815200 & 0.38193500 & -0.77673000 & $\mathrm{C}$ & -4.00335100 & 0.77692600 & -0.83302200 \\
\hline $\mathrm{S}$ & -1.29303400 & 1.70800900 & 0.46074600 & $\mathrm{~S}$ & -1.72601800 & 1.72774600 & 0.57202800 \\
\hline $\mathrm{N}$ & -0.03915400 & 0.67780300 & 0.99343500 & $\mathrm{~N}$ & -0.62514600 & 0.51793700 & 1.05884300 \\
\hline $\mathrm{C}$ & -0.01983000 & -0.62945300 & 0.34621400 & $\mathrm{C}$ & -0.74525500 & -0.73703000 & 0.32397600 \\
\hline $\mathrm{H}$ & -1.33163700 & -2.89346900 & -0.78649200 & $\mathrm{H}$ & -2.27879000 & -2.73413600 & -1.01378300 \\
\hline $\mathrm{H}$ & -3.63337700 & -2.88355800 & -1.74257000 & $\mathrm{H}$ & -4.51951000 & -2.36782300 & -2.04290600 \\
\hline $\mathrm{H}$ & -4.99104500 & -0.81127800 & -1.73220100 & $\mathrm{H}$ & -5.61061300 & -0.14675600 & -1.92344400 \\
\hline $\mathrm{H}$ & -4.06298100 & 1.29594600 & -0.76353700 & $\mathrm{H}$ & -4.47140900 & 1.75409600 & -0.77195600 \\
\hline $\mathrm{O}$ & -0.80477000 & 2.63559700 & -0.56657300 & $\mathrm{O}$ & -1.09183400 & 2.66360400 & -0.36452600 \\
\hline $\mathrm{O}$ & -1.99920500 & 2.25776900 & 1.61737600 & $\mathrm{O}$ & -2.40647200 & 2.27310600 & 1.74625500 \\
\hline $\mathrm{O}$ & 0.87614600 & -0.72944700 & -0.74504300 & $\mathrm{O}$ & 0.17688000 & -0.88316000 & -0.73861800 \\
\hline $\mathrm{C}$ & 2.20851400 & -0.36786700 & -0.56813000 & $\mathrm{C}$ & 1.52950500 & -0.65488800 & -0.49440400 \\
\hline $\mathrm{C}$ & 3.12618700 & -1.25303500 & 0.00792900 & $\mathrm{C}$ & 2.34082900 & -1.62819100 & 0.10508800 \\
\hline $\mathrm{C}$ & 2.62749200 & 0.86657200 & -1.07587100 & $\mathrm{C}$ & 2.09445200 & 0.53356700 & -0.95577800 \\
\hline
\end{tabular}




$\begin{array}{lrrr}\mathrm{C} & 4.47044100 & -0.88342000 & 0.08897200 \\ \mathrm{H} & 2.78304800 & -2.21110100 & 0.37916300 \\ \mathrm{C} & 3.97639700 & 1.22370500 & -0.98817600 \\ \mathrm{H} & 1.90053500 & 1.52525000 & -1.54043700 \\ \mathrm{C} & 4.89927900 & 0.35314400 & -0.40373700 \\ \mathrm{H} & 5.18626700 & -1.56926300 & 0.53412000 \\ \mathrm{H} & 4.30245900 & 2.18181000 & -1.38341400 \\ \mathrm{H} & 5.94722500 & 0.63174000 & -0.33935200 \\ \mathrm{O} & 0.35643000 & -1.63055500 & 1.25418200 \\ \mathrm{C} & -0.37032700 & -1.71250400 & 2.47996300 \\ \mathrm{H} & 0.09799700 & -2.52563500 & 3.03784000 \\ \mathrm{H} & -0.30069800 & -0.78206200 & 3.05005000 \\ \mathrm{H} & -1.42564700 & -1.95576400 & 2.30777300 \\ \mathrm{H} & 0.85883000 & 1.15238500 & 1.00562200\end{array}$

$\begin{array}{lrrr}\mathrm{C} & 3.70279300 & -1.39458500 & 0.25444000 \\ \mathrm{H} & 1.90040900 & -2.55775600 & 0.44495500 \\ \mathrm{C} & 3.46629100 & 0.77110400 & -0.80842100 \\ \mathrm{H} & 1.46206600 & 1.27204800 & -1.43838800 \\ \mathrm{C} & 4.27743300 & -0.19341500 & -0.19658500 \\ \mathrm{H} & 4.34545900 & -2.13819900 & 0.71510000 \\ \mathrm{H} & 3.87731700 & 1.70281200 & -1.17762800 \\ \mathrm{O} & 5.62049800 & -0.07335400 & 0.00343800 \\ \mathrm{O} & -0.53836600 & -1.83521200 & 1.17414600 \\ \mathrm{C} & -1.32149200 & -1.89870900 & 2.36528100 \\ \mathrm{H} & -0.99626600 & -2.80747300 & 2.87539300 \\ \mathrm{H} & -1.14730300 & -1.03013400 & 3.00642500 \\ \mathrm{H} & -2.39213600 & -1.97616800 & 2.14096100 \\ \mathrm{H} & 0.32472900 & 0.87420500 & 1.11572600 \\ \mathrm{C} & 6.27662200 & 1.10640800 & -0.43016800 \\ \mathrm{H} & 7.32700600 & 0.97322600 & -0.16604300 \\ \mathrm{H} & 6.19228700 & 1.24029700 & -1.51605200 \\ \mathrm{H} & 5.88698700 & 1.99661000 & 0.07970200\end{array}$

\begin{tabular}{|c|c|c|c|c|c|c|c|}
\hline \multicolumn{4}{|l|}{$9 c$} & \multicolumn{4}{|l|}{$11 a$} \\
\hline Atom & $\mathbf{X}$ & $\mathbf{Y}$ & $\mathbf{Z}$ & Atom & $\mathbf{X}$ & $\mathbf{Y}$ & $\mathbf{Z}$ \\
\hline $\mathrm{C}$ & -3.00053100 & 0.48221500 & -0.24248400 & $\mathrm{O}$ & -0.00005100 & 2.35443300 & 0.00000000 \\
\hline $\mathrm{C}$ & -2.31946500 & -0.72477000 & -0.32486700 & $\mathrm{C}$ & 0.00000200 & 1.08200400 & 0.00000000 \\
\hline $\mathrm{C}$ & -2.90432300 & -1.80087800 & -0.99029400 & $\mathrm{C}$ & 0.00000700 & 0.28817800 & 1.21398600 \\
\hline $\mathrm{C}$ & -4.16991100 & -1.63038800 & -1.55790200 & $\mathrm{C}$ & 0.00000700 & 0.28817800 & -1.21398600 \\
\hline $\mathrm{C}$ & -4.84345000 & -0.40511900 & -1.46249600 & $\mathrm{C}$ & 0.00000700 & -1.10364700 & 1.20269300 \\
\hline $\mathrm{C}$ & -4.26169000 & 0.67679900 & -0.79801500 & $\mathrm{H}$ & -0.00003200 & 0.83087200 & 2.15864000 \\
\hline $\mathrm{S}$ & -2.02446400 & 1.69735700 & 0.62239500 & $\mathrm{C}$ & 0.00000700 & -1.10364700 & -1.20269300 \\
\hline $\mathrm{N}$ & -0.89945900 & 0.50477900 & 1.11566600 & $\mathrm{H}$ & -0.00003200 & 0.83087200 & -2.15864000 \\
\hline $\mathrm{C}$ & -0.93990400 & -0.71346600 & 0.32427600 & $\mathrm{C}$ & 0.00004600 & -1.83326100 & 0.00000000 \\
\hline $\mathrm{H}$ & -2.38143000 & -2.74897800 & -1.06399500 & $\mathrm{H}$ & 0.00001600 & -1.64148500 & 2.15341600 \\
\hline $\mathrm{H}$ & -4.63822900 & -2.45950400 & -2.08028500 & $\mathrm{H}$ & 0.00001600 & -1.64148500 & -2.15341600 \\
\hline $\mathrm{H}$ & -5.82740900 & -0.29344500 & -1.90822500 & $\mathrm{H}$ & -0.00002100 & -2.92106400 & 0.00000000 \\
\hline $\mathrm{H}$ & -4.77310800 & 1.63025700 & -0.71485800 & & & & \\
\hline $\mathrm{O}$ & -1.40253200 & 2.64887200 & -0.30485100 & & & & \\
\hline $\mathrm{O}$ & -2.72438600 & 2.21634800 & 1.79533200 & & & & \\
\hline $\mathrm{O}$ & -0.01462500 & -0.74046800 & -0.75899800 & & & & \\
\hline $\mathrm{C}$ & 1.32693500 & -0.50492900 & -0.53312800 & & & & \\
\hline $\mathrm{C}$ & 2.15656000 & -1.46904900 & 0.05733400 & & & & \\
\hline $\mathrm{C}$ & 1.86036100 & 0.69995400 & -1.01061800 & & & & \\
\hline $\mathrm{C}$ & 3.51968400 & -1.21690500 & 0.18436800 & & & & \\
\hline $\mathrm{H}$ & 1.73223500 & -2.40258800 & 0.40363400 & & & & \\
\hline $\mathrm{C}$ & 3.22486900 & 0.95172900 & -0.88911200 & & & & \\
\hline $\mathrm{H}$ & 1.19996500 & 1.42529400 & -1.47380300 & & & & \\
\hline $\mathrm{C}$ & 4.03890000 & -0.00958400 & -0.28824700 & & & & \\
\hline $\mathrm{H}$ & 4.18217900 & -1.94605400 & 0.63480000 & & & & \\
\hline $\mathrm{H}$ & 3.65773100 & 1.87647300 & -1.25086200 & & & & \\
\hline $\mathrm{O}$ & -0.64990200 & -1.83531500 & 1.10955300 & & & & \\
\hline $\mathrm{C}$ & -1.42236600 & -2.02229100 & 2.29808600 & & & & \\
\hline $\mathrm{H}$ & -1.03081400 & -2.93364500 & 2.75323700 & & & & \\
\hline $\mathrm{H}$ & -1.30586300 & -1.18167700 & 2.98723300 & & & & \\
\hline $\mathrm{H}$ & -2.48484000 & -2.16124200 & 2.06804000 & & & & \\
\hline $\mathrm{H}$ & 0.02653700 & 0.89273400 & 1.26656600 & & & & \\
\hline $\mathrm{N}$ & 5.48350900 & 0.25210000 & -0.15451300 & & & & \\
\hline $\mathrm{O}$ & 6.17146700 & -0.60951900 & 0.38849900 & & & & \\
\hline $\mathrm{O}$ & 5.91399100 & 1.31590700 & -0.59319500 & & & & \\
\hline
\end{tabular}

